\author{
اثرات يذيرش فناورى خاكورزى حفاظتى بر عملكرد كندم، مصرف آب و فقر خانوار \\ سودابه مطلبانى، منصور زيبايى و آذر شيخ زينالدين ا”

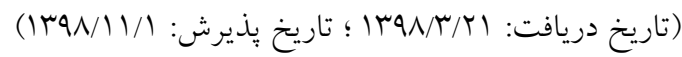

جكيده

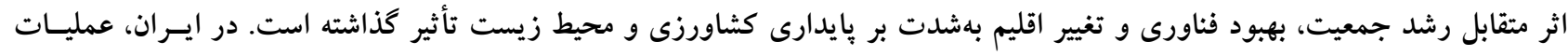

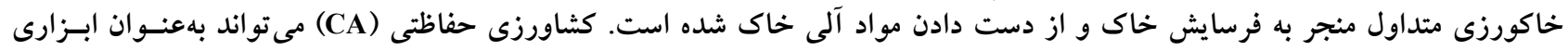

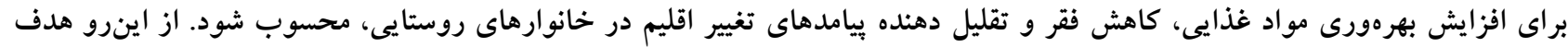

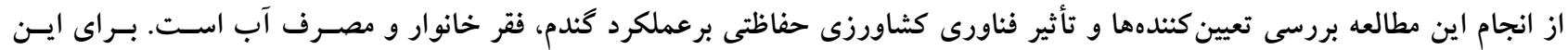

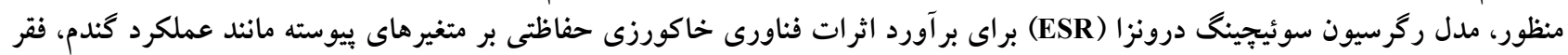

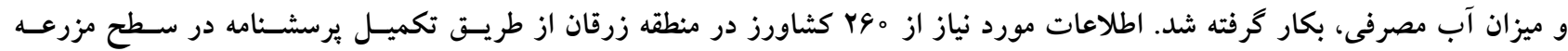

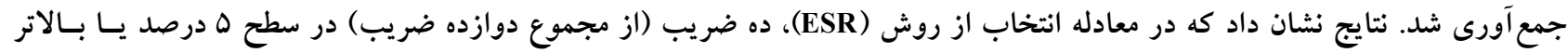

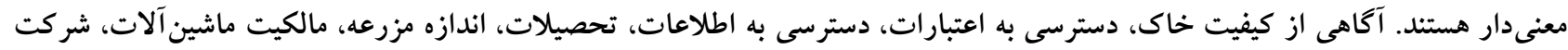

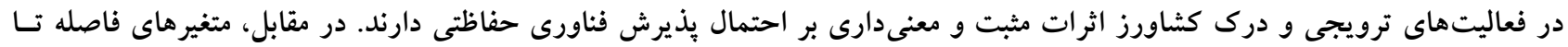

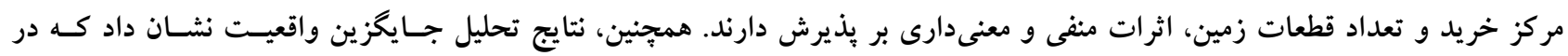

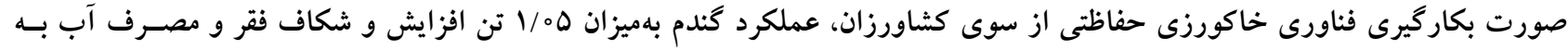

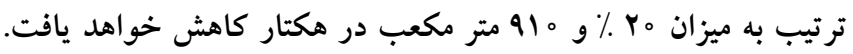

وازههاى كليدى: مدل رگرسيون سوئيجينگ درونزا، تحليل جايكزين واقعيت، مديريت بايدار، زرقان

1. كروه اقتصاد كشاورزى، دانشخاه شيراز

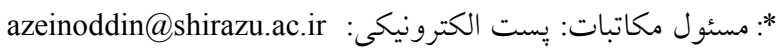


سطحى خاى را كاهش مى دهد و بهعنوان يكى عايق حرارتى

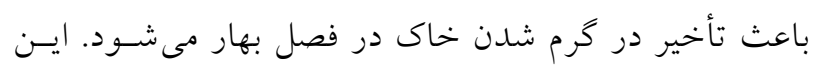

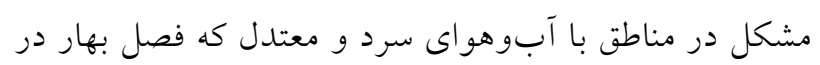

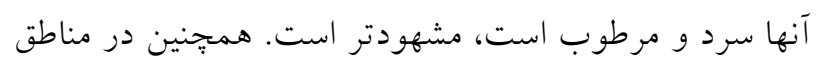

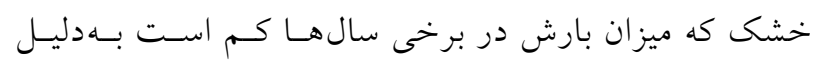

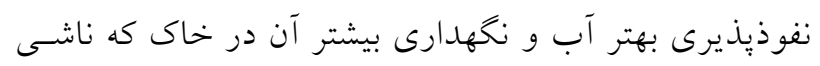

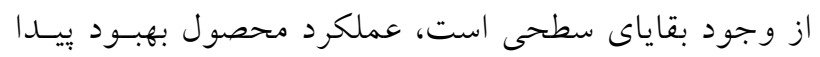

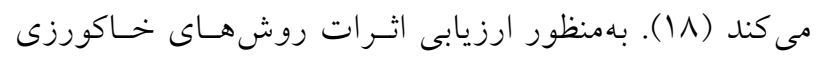

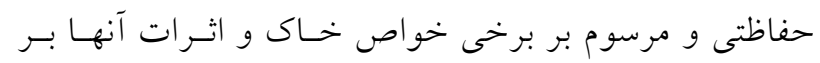
عملكرد مطالعات مختلفى انجام شده است. جالتا و همكاران

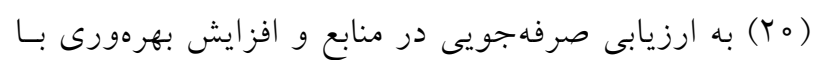

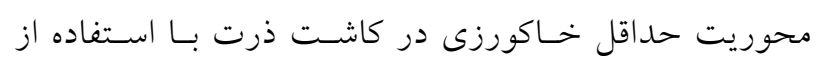

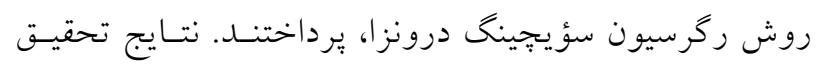

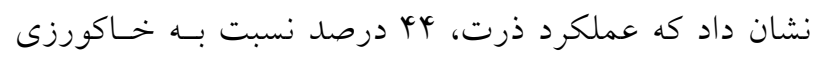

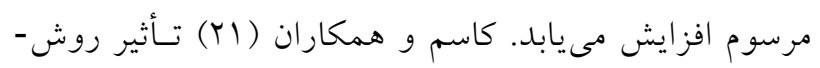

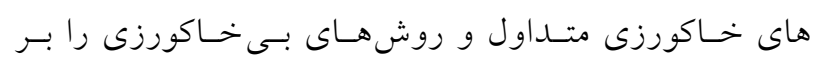

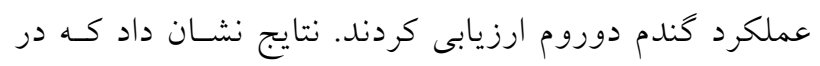

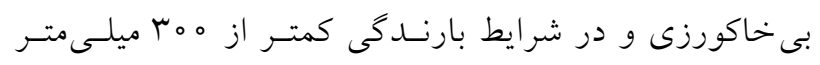

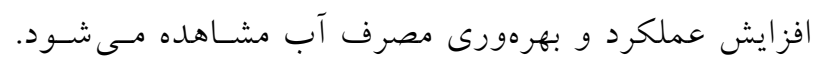

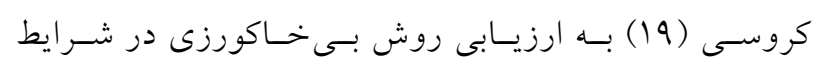

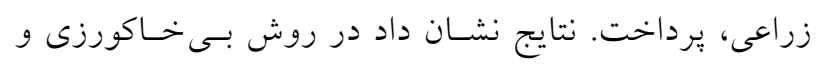

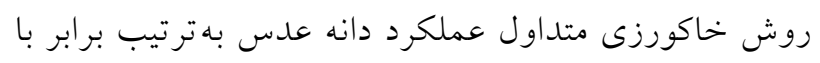

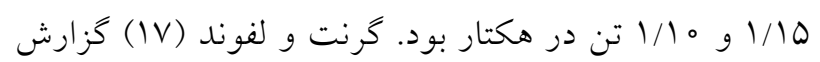

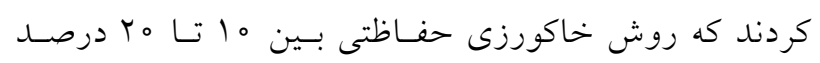

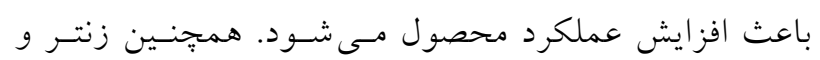

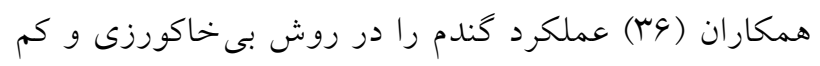

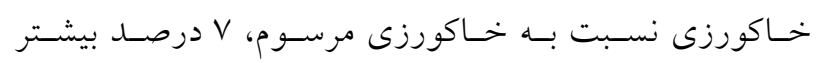

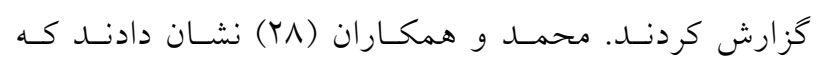

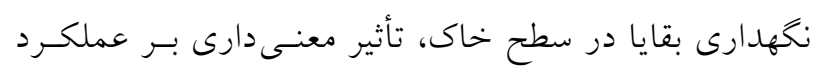

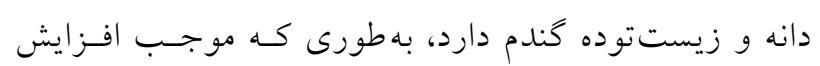

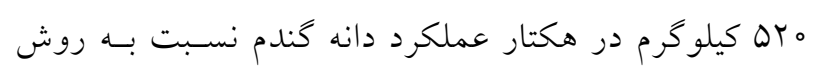

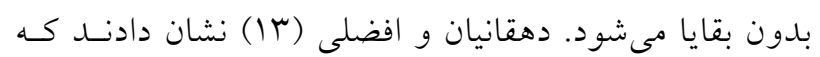

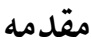

توليد محصولات كشاورزى نيازمند منابع توليد بهويزه آب و

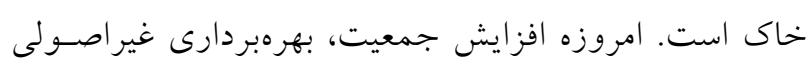

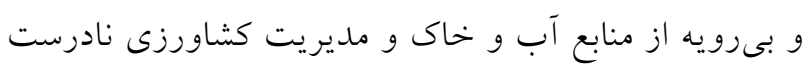

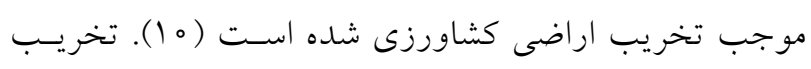

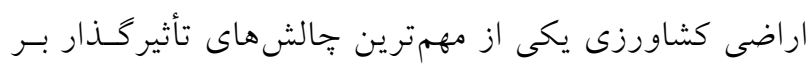

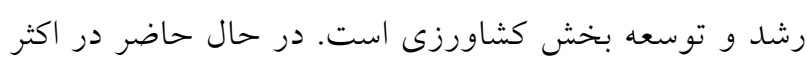
اراضى كشاورزى كشـور، كشـاورزان بــراى انجـام عمليـات

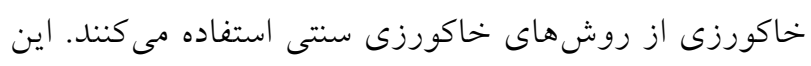

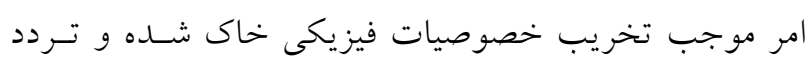

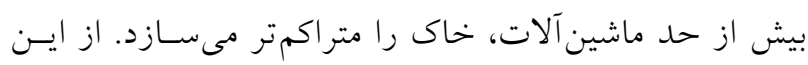

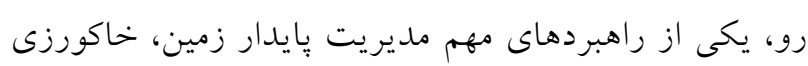

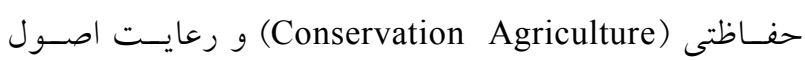

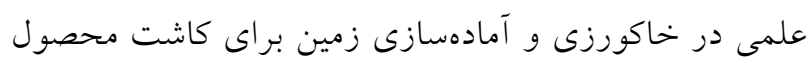

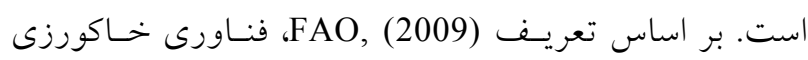
حفاظتى مفهومى براى توليد محصولات كشاورزى و صـرفه-

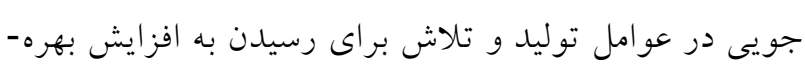

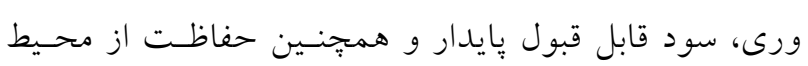

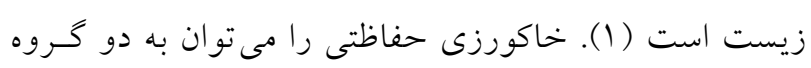

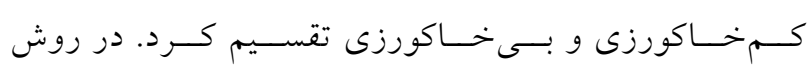

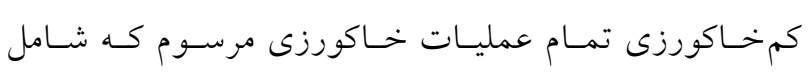

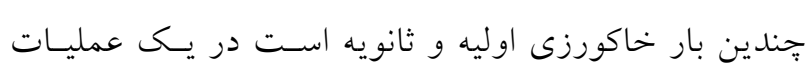
توسط خاكورز مركب انجام مى شـود و وِس از آن آن عمليـات

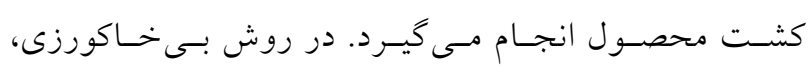

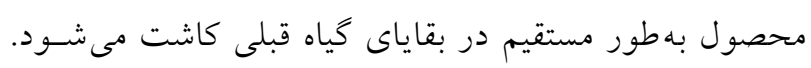

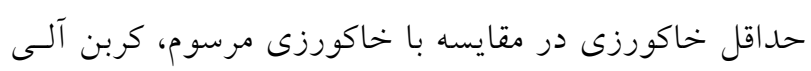

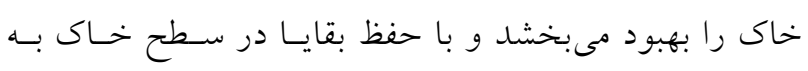

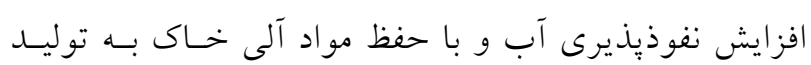

لايدار محصولات كشاورزى منجر مى شود (Y) (Y).

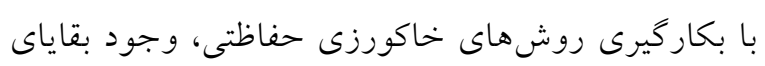
كياهى سطحى خاى باعث انعكاس تابش خورشيد مى شـوند

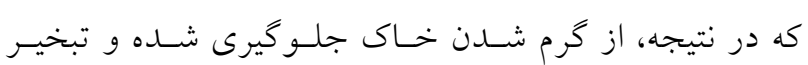


اثرات علّى يذّيرش فناورى، نشان دادنــــ كـه دسترسـى بــه

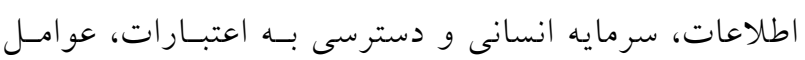
محدودكننده كليدى در بذيرش فناورى خاكورزى حفاظتى

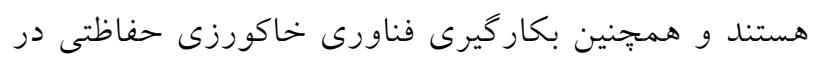

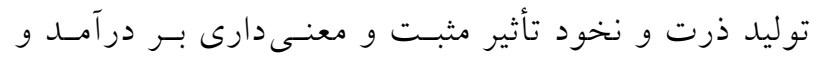

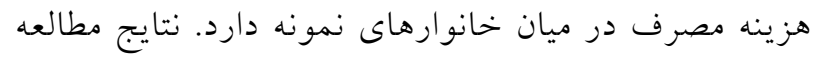

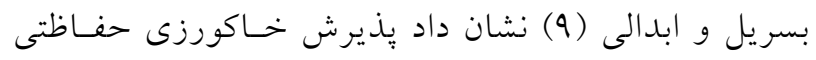

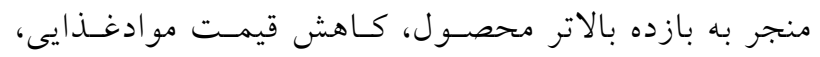

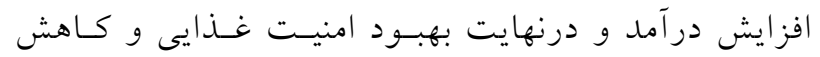

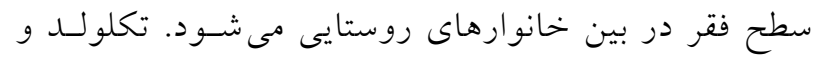

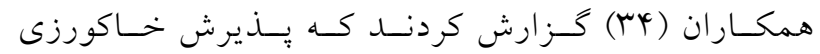
حفاظتى، اثرات مثبتى بر درآمـــ خـانوار داشـته و تقاضـاى

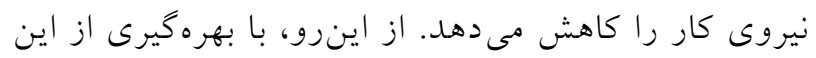
فناورىها مى توان امنيت غذايى خانوار را از طريق افزايش

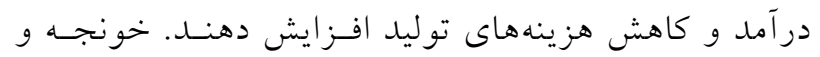

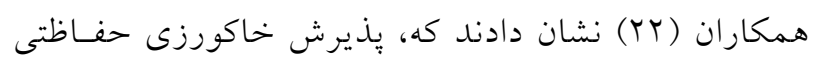

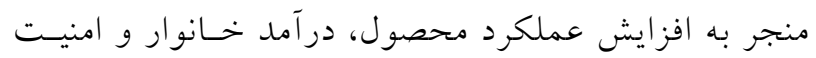
غذايى شده است.

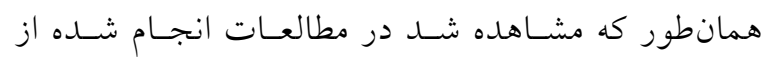

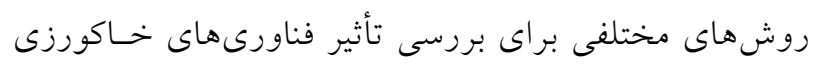

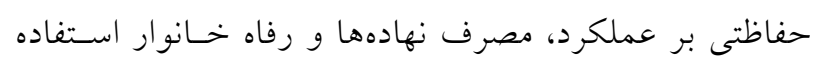

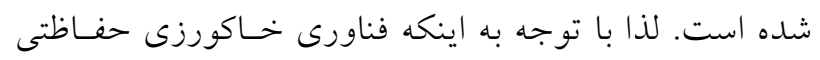

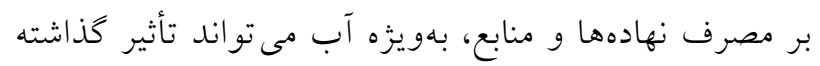

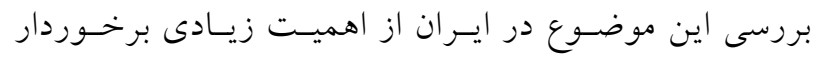
است كه در اين مطالعه به طور خاص مورد توجه قرار كرفته

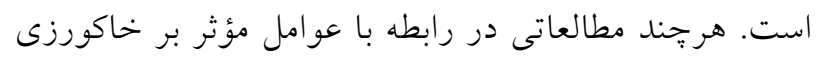

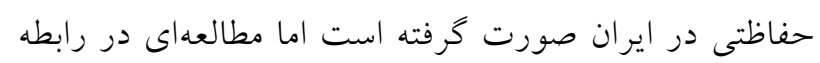

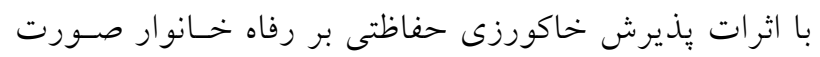

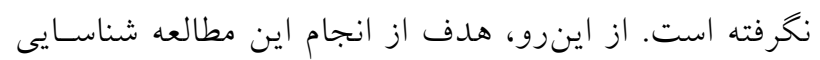

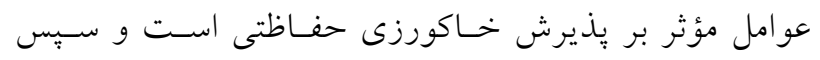

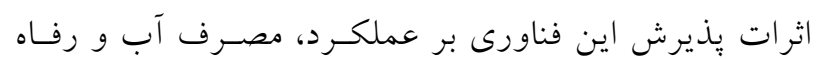

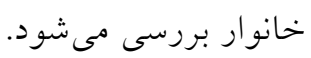

سيستم خاكورزى حفاظتى باعث كاهش مصسرف سـوخت و

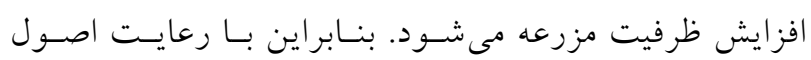

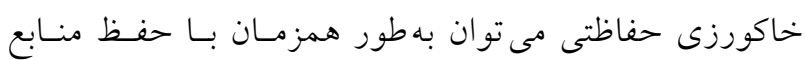

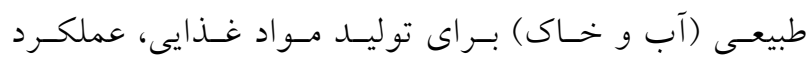

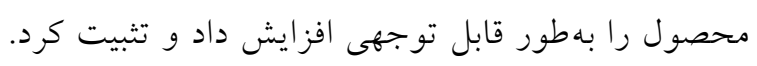

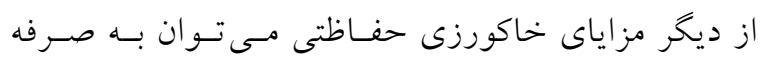

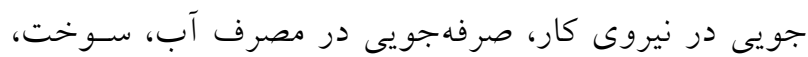
علفكشها و كاهش هزينهاى توليد و حاصـلخيزى بايسـار

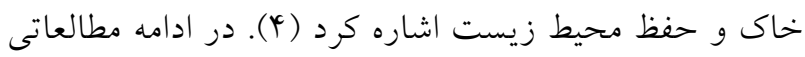

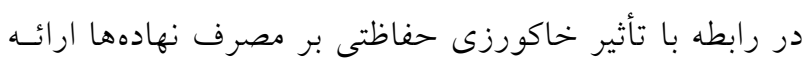
شده است. يافته هاى روكستورم و همكاران (آس) نشان دادند

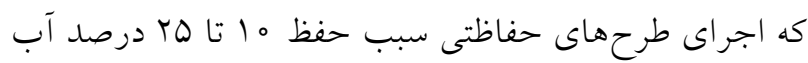

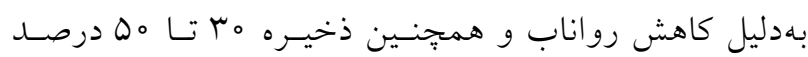
باقى مانده بهدليل كاهش تبخير از سطح خهـاك داراى يوشـش

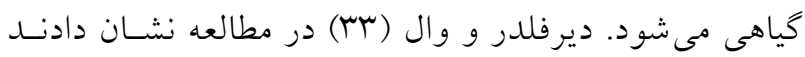

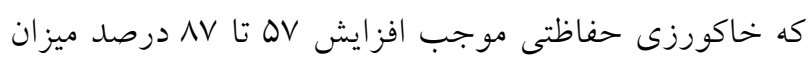

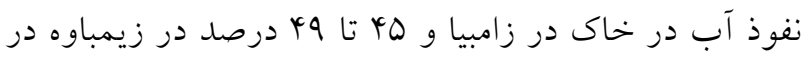
مقايسه با كشت مرسوم مى شود. موسـوى و همكـاران (Y9)،

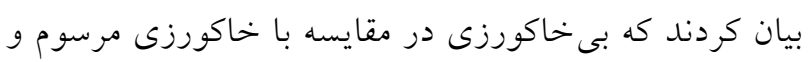

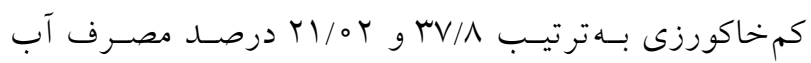
كمترى دارد. در اغلب كشورهاى در حال توسعه، بهبود كسـبووكـار

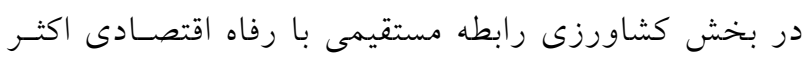

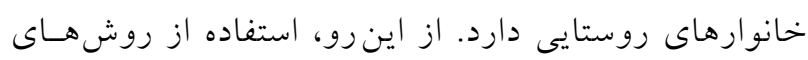

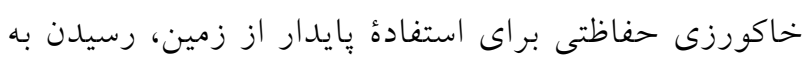

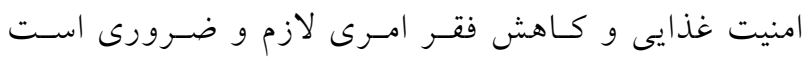

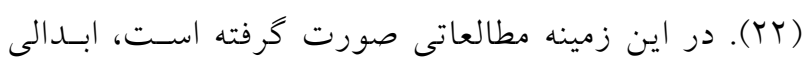

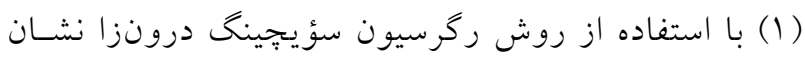

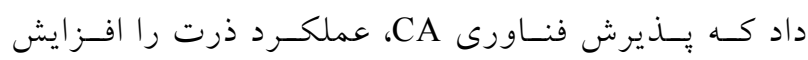
مى دهــد و باعـث كـاهش فقـر خـانوار مسى شـود. اسـفو و

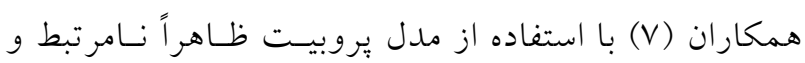
روش Propensity Score Matching) PSM) براى تحليـل مدرد 
جامعهُ مورد تحقيق نامحدود، گسترده و بر اكنده اسـت و امكـان

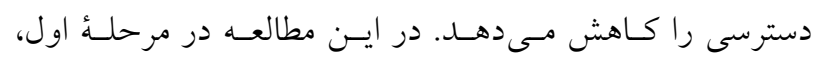

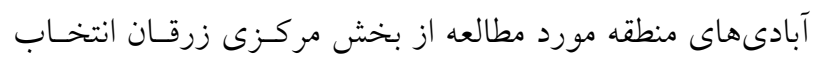

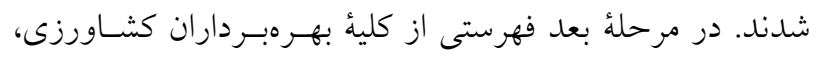

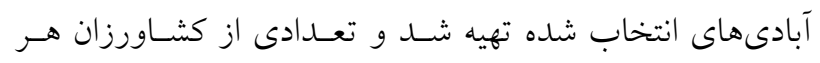

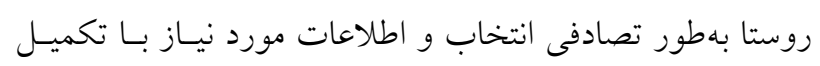

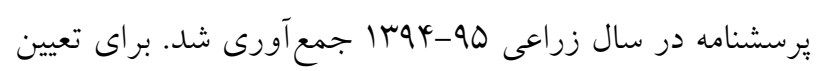
حجم نمونه از فرمول كوكران، استفاده شد:

$$
\mathrm{n}=\frac{\frac{\mathrm{Z}^{2} \mathrm{pq}}{\mathrm{d}^{2}}}{1+\frac{1}{\mathrm{~N}}\left(\frac{\mathrm{Z}^{2} \mathrm{pq}}{\mathrm{d}^{2}}-1\right)}
$$

كه در اين فرمول، n حجم نمونسه، P تخمسين نسـبتى از جامعسه

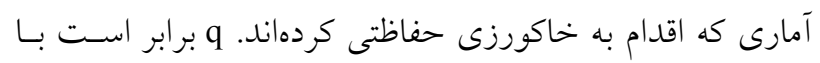
(1-p)

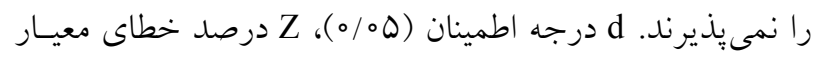

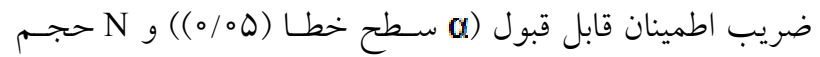

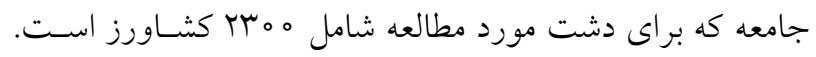

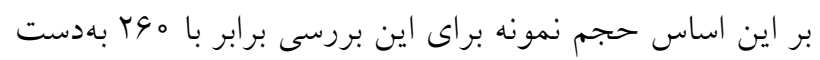

اثر بذيرش فناورى CA بر متغيرهاى بيوسته (عملكرد محصـول و مصرف نهاده) و متغيرهاى باينرى مانند فقر، با استفاده از داده

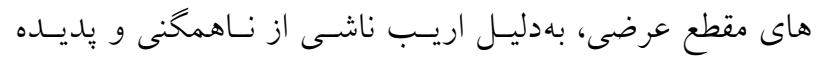

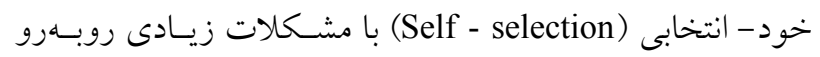
است. در اين مطالعه به ييروى از مطالعات ابــالى (1)، ديفـالكو

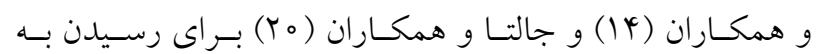

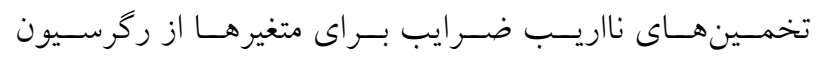

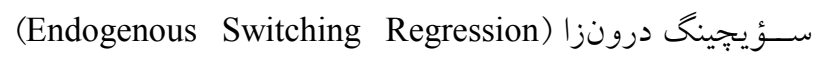

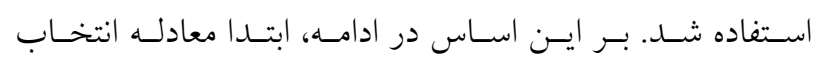

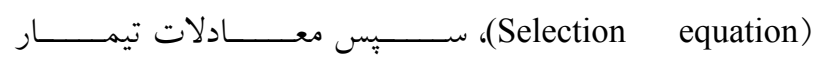
و درنهايت تجزيسهو تحليـل جـايكزين (Treatment equations)

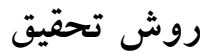

\section{منطقه مورد مطالعه و جامعه آمارى}

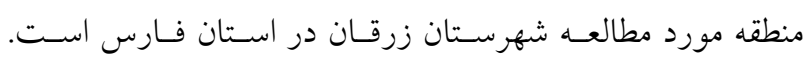

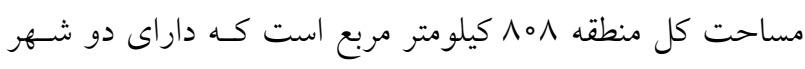

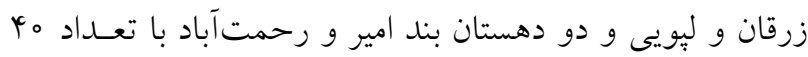

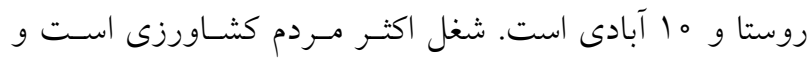

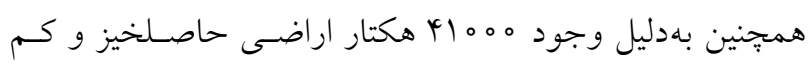
نظير كشاورزى كه قسمت اعظم آن در حوضه آبريز رودخانه كُر بهر

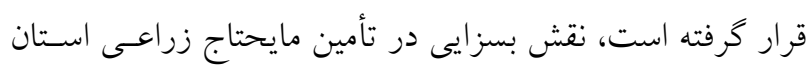

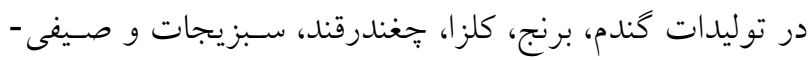

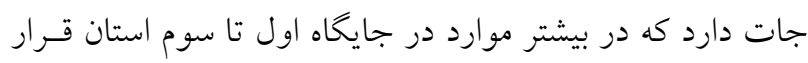

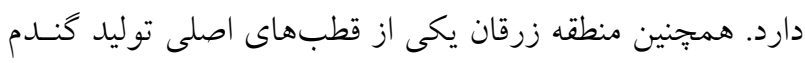
در شيراز است كه همه ساله علاوه بر توليد حجم وسيعى از اين

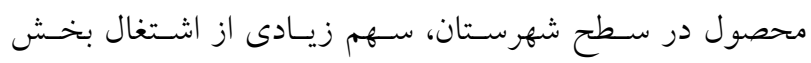

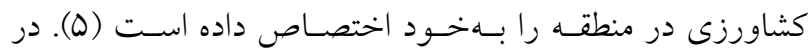

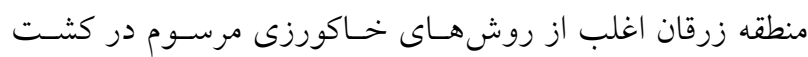

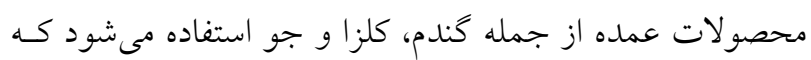

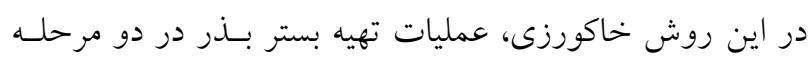

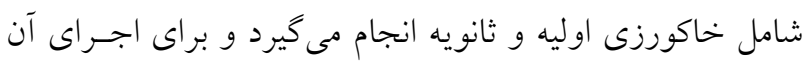

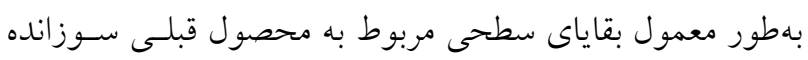

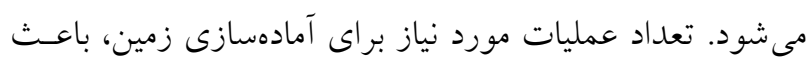

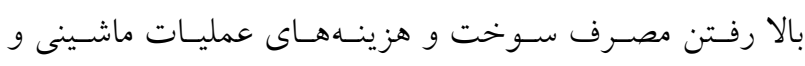

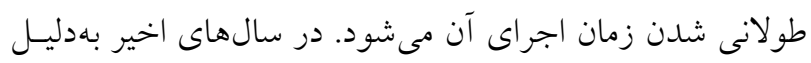

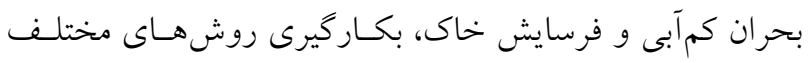

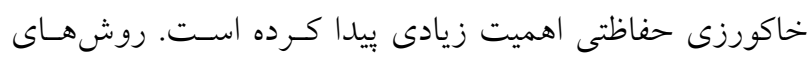

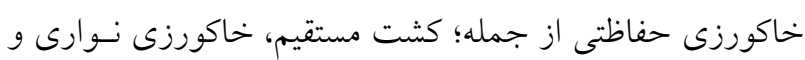
خاكورزى يشتهاى در اين بخش مورد استفاده قرار كرفته اسـت و تقريباً در تمام مناطق اين بخش كشاورزانى هستند كه كـاربرد

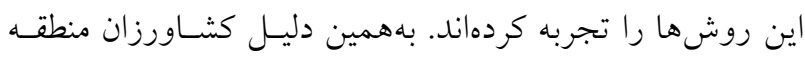

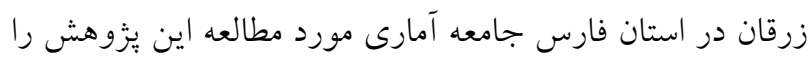

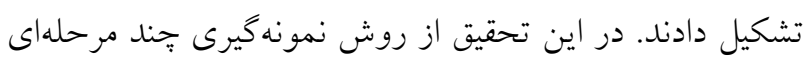
تصادفى (Multistage Random Sampling) استفاده شــ، زيـرا 
Re gime1: $Y_{i, A}=Z_{i, A}^{\prime} \beta_{i, A}+\mu_{i ., A}$

(براى كشاورزانى كه اقدام به خاكورزى حفاظتى كردهاند.)

Re gime 2: $Y_{i, N}=Z_{i, N}^{\prime} \beta_{i, N}+\mu_{i, N}$

(براى كشاورزانى كه خاكورزى حفاظتى را نيذير فتهاند.)

متغيرهاى وابسته در دو گروه از بذيرنسدكان و YiN و YiA

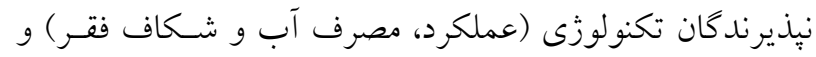
بردار متغيرهاى مستقل شامل متغيرهاى اقتصـادى- Z Z Z Z Z

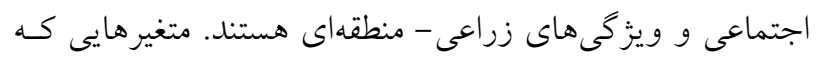

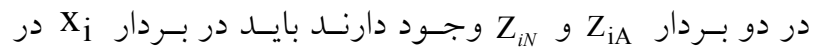

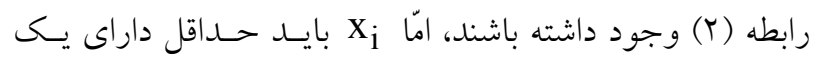
متغير بيشتر باشد كه در $Z_{\text {IA }}$

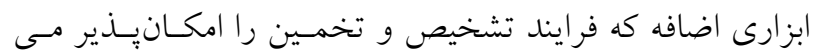
سازد در تحقيق حاضر عبارت است از اسـتنباط خـانوار از ايسن

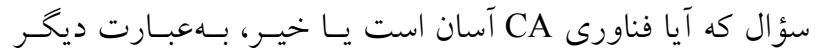

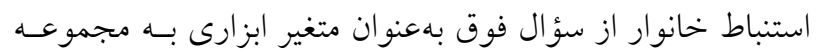

متغيرهاى مستقل معادله انتخاب (Y) اضافه شد (Y) (Y).

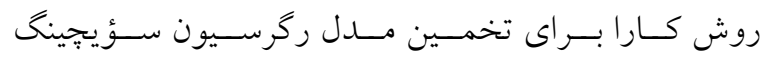

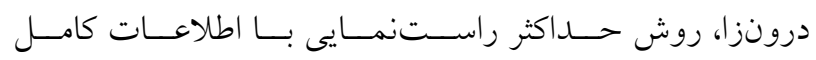
(Full Information Maximum Likelihood (FIML))

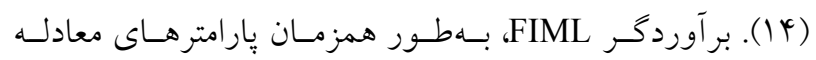

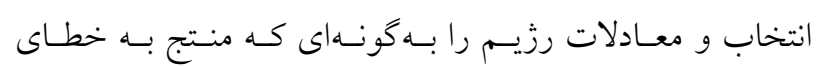

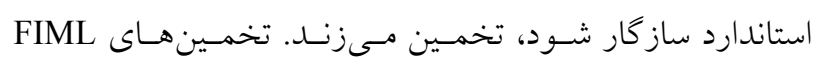

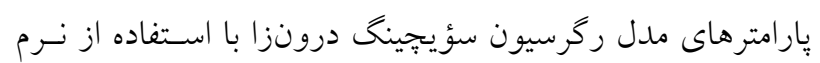
افزار STATA و نصب دستور movestay بهدست مي آيد. مدل مدرل

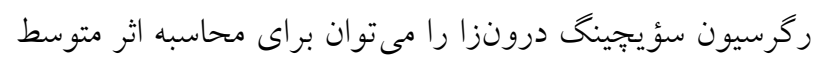

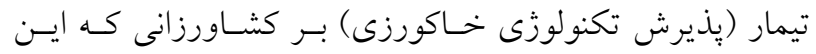
(ATT) نs

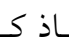

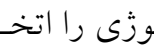
تكنولـ Average Treatment on Treated نكردهانـد Average Treatment on Untreated (ATU) بكــار برد (ه) إين كار بهطور ساده از طريق مقايسـه ارزش انتظـارى

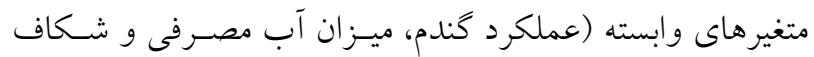
فقر) براى كشاورزانى كه ايسن تكنولـوزى را اتخــاذ كــدهانـــ و
واقعيت (Counterfactual analysis) بـهـطـور خلاصـه توضسيح

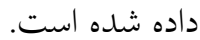
مدل ESR يكى روش دو مر حلـهاى اسـت كـه در خـام اول،

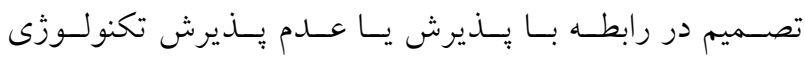

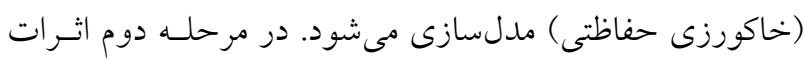
يذيرش تكنولوزى بر متغيرهاى مورد نظـر (عملكــد محصـول،

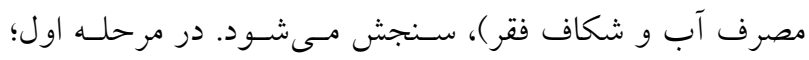
فرض مىشود كه تصميم زارع براى يذيرش خاكورزى حفاظتى مصنى

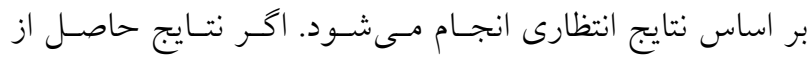

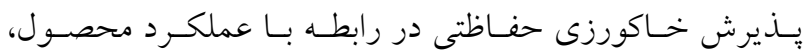
مصرف آب و شكاف فقر نسبت بـه وضـعيت ايـن متغيرهـا در

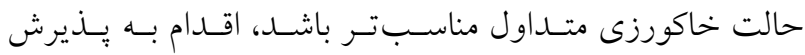
خاكورزى حفاظتى خو اهد كرد.

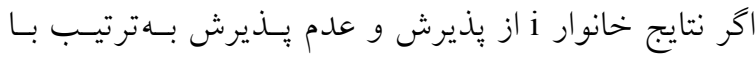

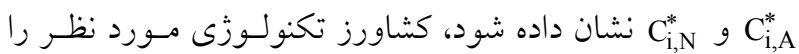

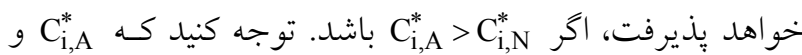

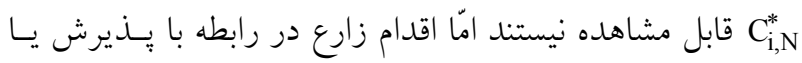

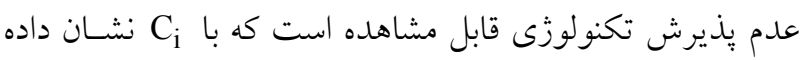

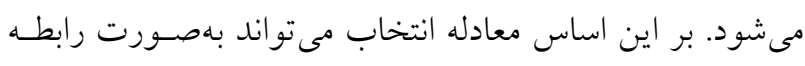

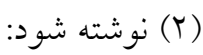

$$
\begin{aligned}
& \mathrm{C}_{\mathrm{ij}}=\mathrm{x}_{\mathrm{i}}^{\prime} \alpha+\varepsilon_{\mathrm{i}} \quad \mathrm{j}=\{\mathrm{A}, \mathrm{N}\} \\
& \mathrm{C}_{\mathrm{i}}=1 \quad \mathrm{C}_{\mathrm{i}, \mathrm{A}}^{*}>\mathrm{C}_{\mathrm{i}, \mathrm{N}}^{*} \\
& \mathrm{C}_{\mathrm{i}}=0 \quad \text { در غير اين صورت }
\end{aligned}
$$

يك متغير باينرى است كه ارزش آن براى كشـاورزانى كـهـ فناورى را مى يذيرند يك و در غير اينصورت صفر استت. X شامل تمام متغيرهاى اقتصادى - اجتماعى، ويزگى هاى زراعى و منطقهاى است كه بر فرايند تصميمسازى در خصـوص يـــيرش يا عدم يذيرش مؤثر هستند.

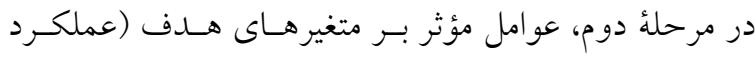
محصول، مصرف آب و شكاف فقر) در دو گروه از يذيرنـدگان

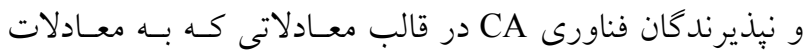
رزيم يا معادلات تيمار كفته مىشوند، ارزيابى شد: 
لازم بهذكر است، تكنولوزى CA مى تواند درآمد خـانوار

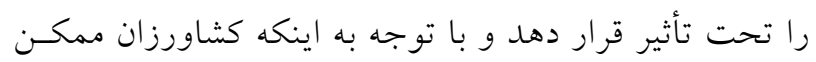

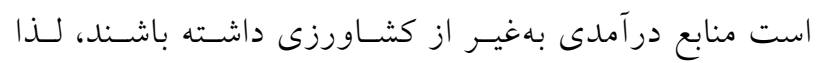

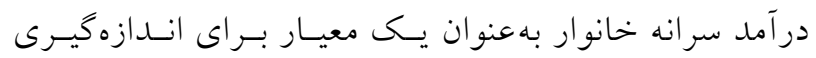

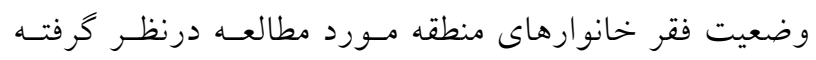

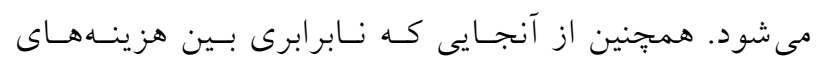

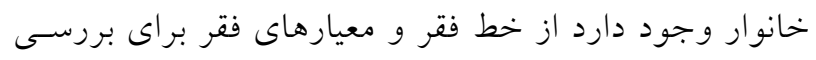
وضعيت فقر خانوارهـاى روسـتايى استفاده شـــ (19)، كـهـ بهصورت رابطه (ه ) است: $\mathrm{S}=0,1,2$

$\mathrm{p}_{\mathrm{n}}=\frac{1}{\mathrm{~N}} \sum_{\mathrm{i}=1}^{\mathrm{P}}\left(\frac{\mathrm{L}-\mathrm{K}_{\mathrm{i}}}{\mathrm{L}}\right)^{\mathrm{s}}$

با توجه به رابطه (م)1)، شاخص فقـر، N عـل نمونـه، تعلداد خانو ادههاى فقير، L خط فقر و K درآمد سرانه خانوار و Sقياس فقر است. شاخص سرشمار فقر، خانوادههـاى فقيــر و و

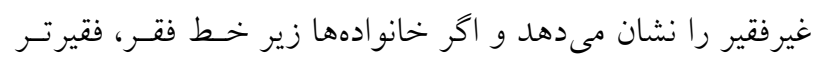

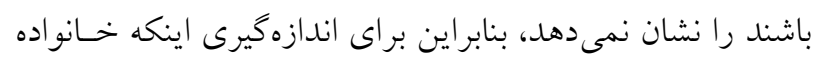
ها جهه اندازه فقير هستند از شاخص شكاف فقـر استفاده شـده است. براى محاسبه شاخص سرشمار فقر قيارامتر S مقدار صـفر

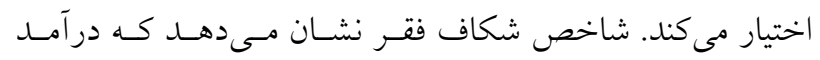

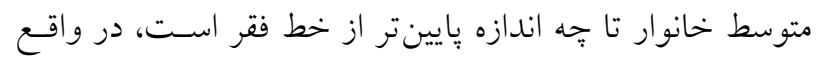
شاخص شكاف فقر بهعنوان درصــى از خـط فقـر بيـان شــهـ است. براى محاسبه شاخص شكاف فقر نيز S مقدار يك اختيـار

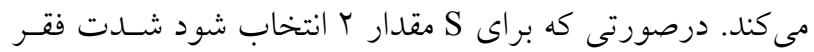
را نشان خواهد داد.

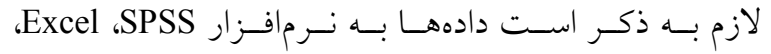

STATA و متتقل و تخمينهاى مورد نظر انجام شد.

\section{نتايج}

اطلاعات فراهم آمده از موب يرسشنامه در رابطه با ويزّكىهـاى اقتصادى و اجتماعى بهرهبرداران نمونه در جدول (1) ارائه شده
كشاورزانى كه اين تكنولوزى را اتخـاذ نكـردهانـــ در وضـعيت

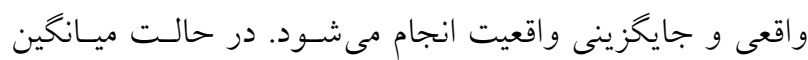

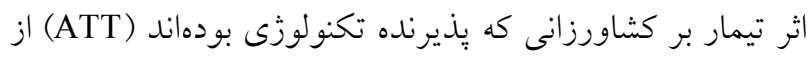
رابطه (ه) محاسبه مىشود: $\mathrm{ATT}=\mathrm{E}\left(\mathrm{Y}_{\mathrm{iA}} \mid \mathrm{C}_{\mathrm{i}}=1\right)-\mathrm{E}\left(\mathrm{Y}_{\mathrm{iN}} \mid \mathrm{C}_{\mathrm{i}}=1\right)$

كه در آن E(

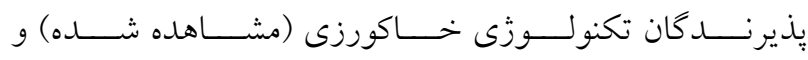

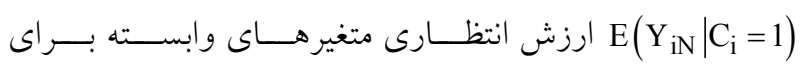
يذّيرندكان در صورت عدم يذيرش فناورى خاكورزى حفـاظتى

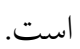
بهلطور مشابه متوسط اثر تيمار بر كشاورزانى كـه تكنولـوزى

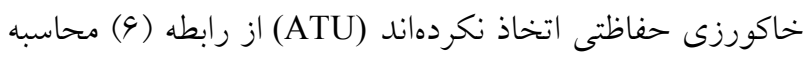
$\mathrm{ATU}=\mathrm{E}\left(\mathrm{Y}_{\mathrm{iN}} \mid \mathrm{C}_{\mathrm{i}}=0\right)-\mathrm{E}\left(\mathrm{Y}_{\mathrm{iA}} \mid \mathrm{C}_{\mathrm{i}}=0\right)$

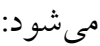

كـــــهـ در آن E(

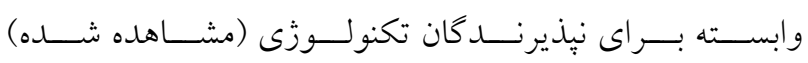

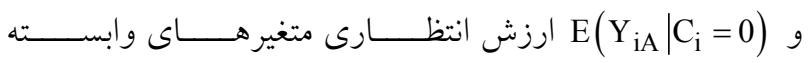
براى نيذيرندكان درصـورتى كـه فنـاورى حفـاظتى را بيذيرنسا،

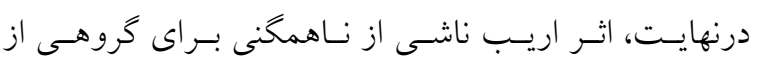

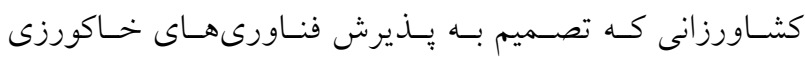
حفاظتى دارنــ (BH)( The effect of Base Heterogeneity) از

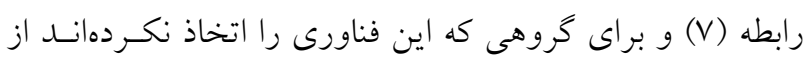
رابطه (N) محاسبه شد:

$$
\begin{aligned}
& \mathrm{BH}_{1}=\mathrm{E}\left(\mathrm{Y}_{\mathrm{iA}} \mid \mathrm{C}_{\mathrm{i}}=1\right)-\mathrm{E}\left(\mathrm{Y}_{\mathrm{iA}} \mid \mathrm{C}_{\mathrm{i}}=0\right) \\
& \mathrm{BH}_{2}=\mathrm{E}\left(\mathrm{Y}_{\mathrm{iN}} \mid \mathrm{C}_{\mathrm{i}}=1\right)-\mathrm{E}\left(\mathrm{Y}_{\mathrm{iN}} \mid \mathrm{C}_{\mathrm{i}}=0\right)
\end{aligned}
$$

تفاوت بين اثرات فناورى خاكورزى حفاظتى بين يذيرندكان

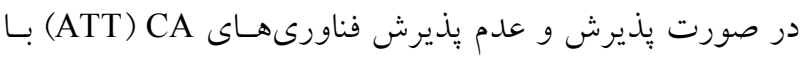

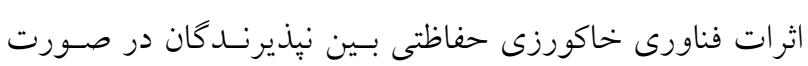

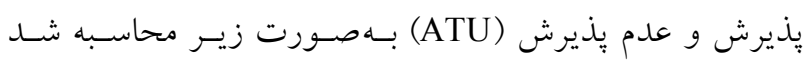
:(Transitional Heterogeneity (TH))

$\mathrm{TH}=\mathrm{ATT}-\mathrm{ATU}$ 
جدول ا. ويزّكىهاى اقتصادى و اجتماعى بهرهبرداران نمونه

\begin{tabular}{|c|c|c|c|}
\hline درصد & فراوانى & دامنه & شرح \\
\hline$r q / 9$ & $10 r$ & $\varphi \Delta-r_{\circ}$ & \multirow{3}{*}{ سن (سال) } \\
\hline$r \Delta / 4$ & 111 & $90-Y Q$ & \\
\hline 10 & rq & $V \wedge-90$ & \\
\hline $9 / \pi$ & 19 & مجرد & \multirow{2}{*}{ وضعيت تأهل } \\
\hline $9 r / 1$ & YKY & متأهل & \\
\hline$\mu \circ / r$ & 19 & بي سواد & \multirow{5}{*}{ تحصيلات } \\
\hline$\Lambda / \Lambda$ & r & ابتدايى & \\
\hline $1 r / 9$ & 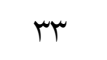 & سيكل & \\
\hline$r 1 / 9$ & $\Delta r$ & ديبم & \\
\hline $19 / 0$ & pr & تحصيلات عالى & \\
\hline$V \varphi / r$ & $19 \pi$ & عدم اشتغال & \multirow[b]{2}{*}{ اشتغال خارج از مزرعه } \\
\hline$r Q / \Lambda$ & $9 V$ & اشتغال & \\
\hline $11 / r$ & rq & زير ها سال & \multirow{4}{*}{ سابقه كار كشاورزى } \\
\hline Me/r & 94 & ها تا هr سال & \\
\hline 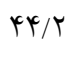 & 110 & هץ تا هץ سال & \\
\hline$\Lambda / \Delta$ & rt & ه† سال و بالاتر & \\
\hline$\Lambda \Delta / 4$ & Trt & مالى & \multirow{4}{*}{ مالكيت اراضى كشاورزان } \\
\hline $11 / r$ & rq & سهمبرى & \\
\hline $1 / r$ & $\varphi$ & اجاره & \\
\hline $1 / 9$ & $\Delta$ & مختلط & \\
\hline$\Delta \psi / 9$ & IFY & جاه & \multirow{5}{*}{ منبع تأمين آب } \\
\hline TY/Q & st & سد & \\
\hline$\Lambda / 1$ & rI & جاه و سد & \\
\hline$r / \Lambda$ & 10 & جِاه اشتراكى و سد & \\
\hline$\Lambda / \Lambda$ & r & جاه اشتراكى & \\
\hline$\Delta q / r$ & lQY & عدم آتش زدن بقاياى محصول & \multirow{2}{*}{ سوزاندن كاه و كلش } \\
\hline$r \circ / \Lambda$ & 109 & آتش زدن بقاياى محصول & \\
\hline $91 / \pi$ & 109 & عدم رعايت آيش گذارى & \multirow{2}{*}{ 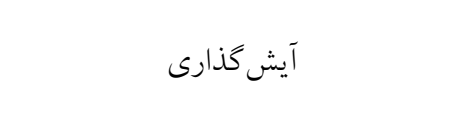 } \\
\hline 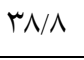 & 101 & رعايت آيش گذارى & \\
\hline $49 / 4$ & $|r|$ & 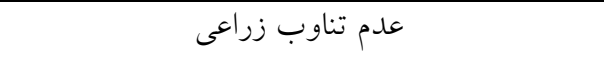 & \multirow{2}{*}{ 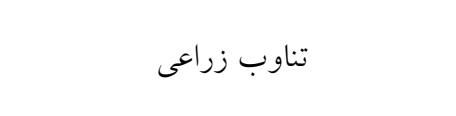 } \\
\hline$\Delta r / r$ & 149 & 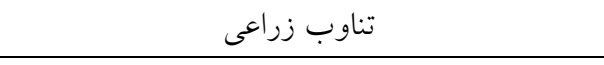 & \\
\hline $9 \% / 0$ & 101 & مرسوم & \multirow{3}{*}{ روشهاى خاكورزى } \\
\hline $19 / 0$ & r & 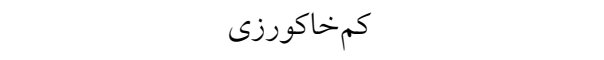 & \\
\hline$T r / 9$ & 09 & 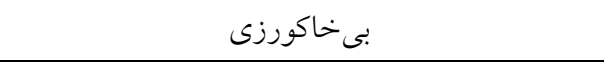 & \\
\hline KT/V & 111 & كشاورزانى كه فناورى خاكورزى حفاظتى را مىيذيرند. & \multirow[t]{2}{*}{ يذّيرش فعاليتهاى خاكورزى حفاظتى } \\
\hline$\Delta \vee / r$ & 149 & كشاورزانى كه فناورى خاكورزى حفاظتى را نمى يذيرند. & \\
\hline
\end{tabular}


بيردازد. همجنين رابطه مثبت و معنى دار شركت در كلاسهاى

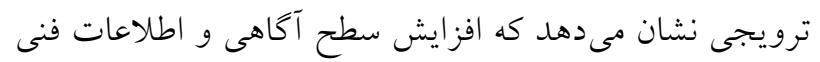

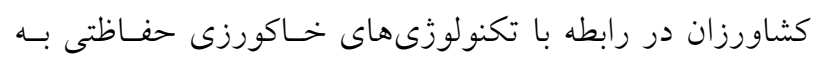

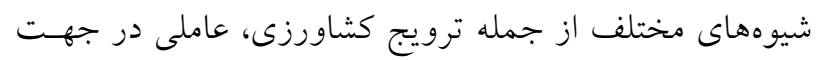

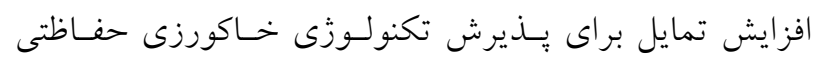

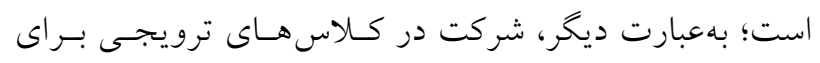

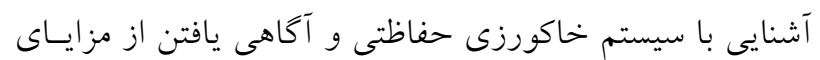

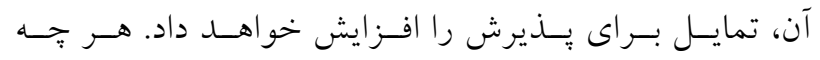

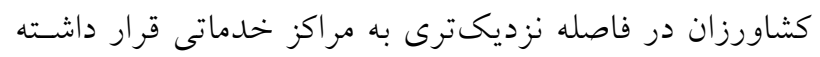

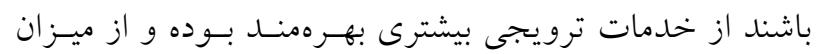

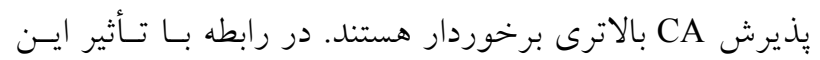

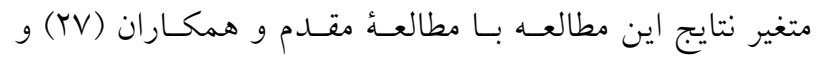

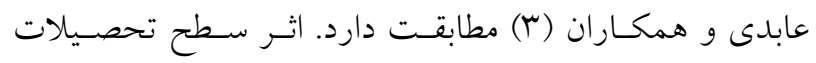
مثبت و معنى دار است. يعنى هـر جـهـ تحصـيلات كشـاورزان

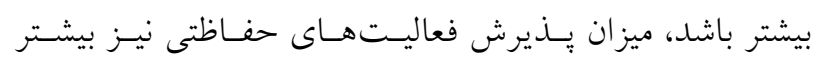

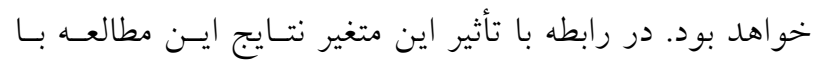

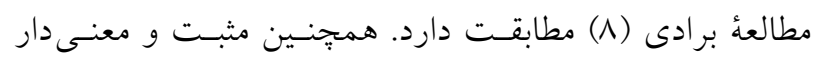

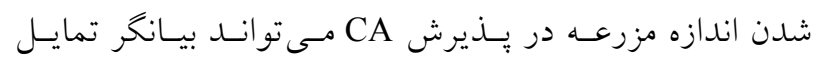

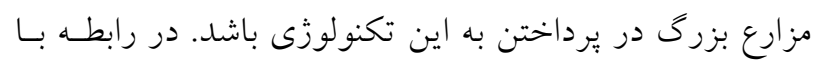

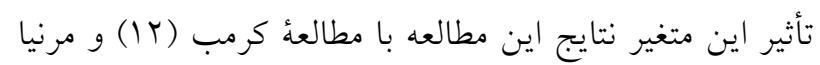

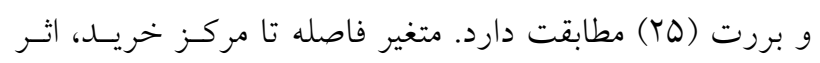
منفى و معنى دارى بر بذيرش فعاليتهاى حفاظتى دارد؛ يعنسى

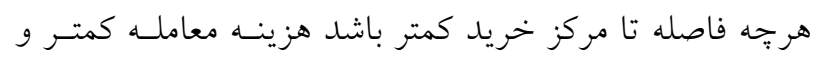

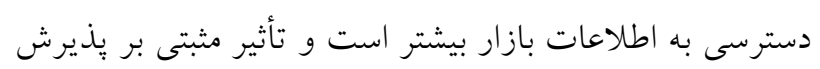

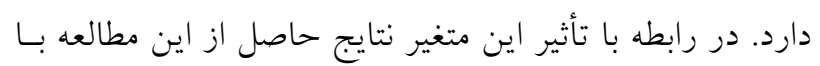

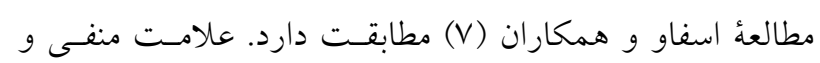

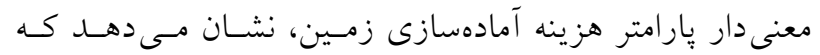
افزايش هزينههاى خاكورزى حفاظتى نسبت به مرسوم، تمايسل

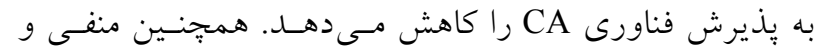
معنى دار شدن هزينه كودهاى شيميايى در بـــيرش خـاكورزى

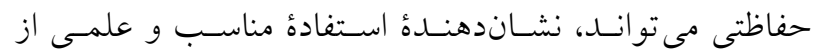

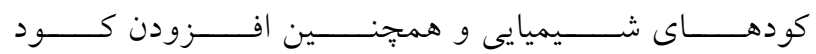

جدولهـاى (Y) تـا (Y)، نتسايج حاصـل از تخمسين ركرسـيون

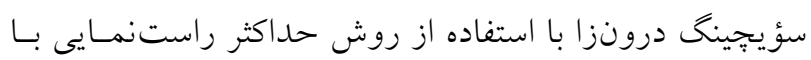

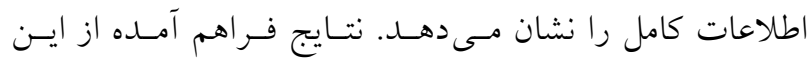

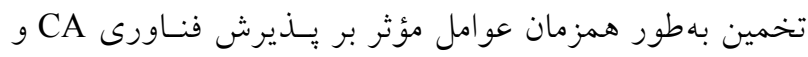

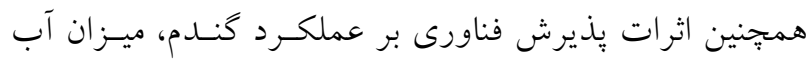

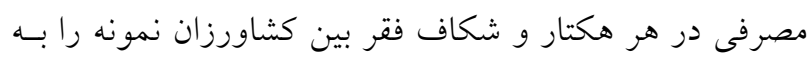
دست مى دهد. بررسى مطالعات مختلف نشان داد كه ويزكى هـــاى فـردى (سن، تحصيلات، سابقه كشاورزى و مالكيت زمسين)، ويزگى

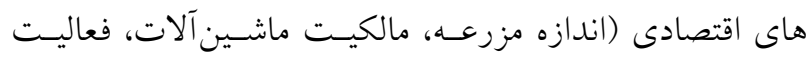

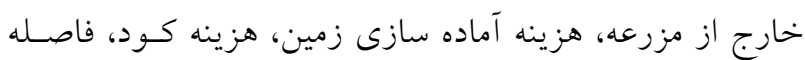

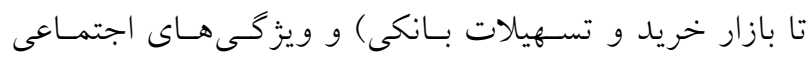

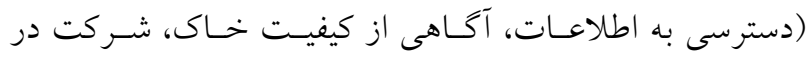

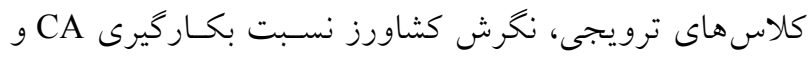

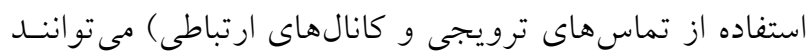

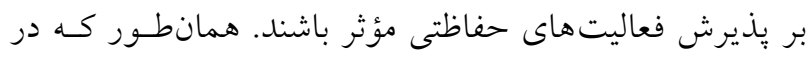

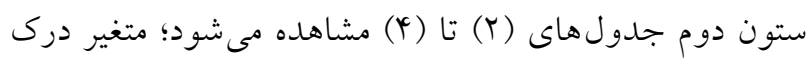

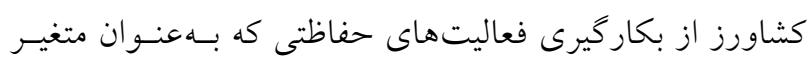

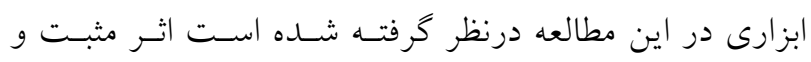

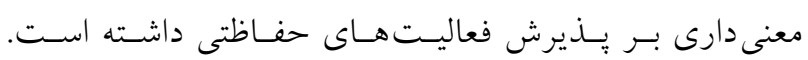

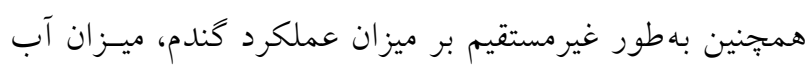

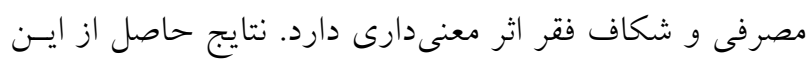

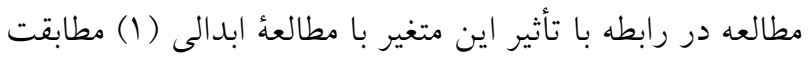

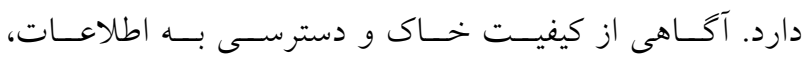

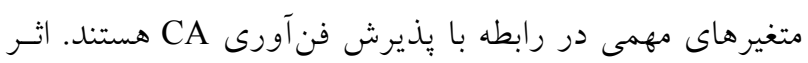

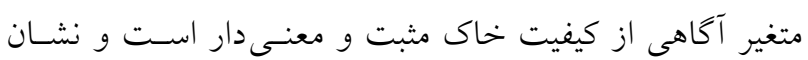

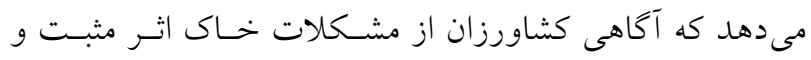
معنى دارى بر ثيذيرش فناورى CA دارد. در رابطه با تـأثير ايسن

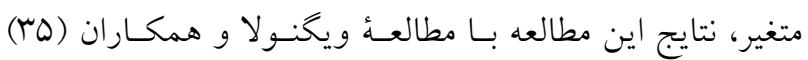

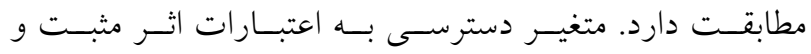
معنى دارى بر بذ يذيرش خـاكورزى حفـاظتى دارد. اعتبـارات بـهـ

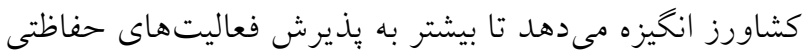


جدول r. نتايج حاصل از عوامل مؤثر بر بذيرش خاكورزى حفاظتى و اثر آن بر عملكرد گندم بين دو گروه از يذيرندگان و نِذيرندگان

\begin{tabular}{|c|c|c|c|c|c|c|}
\hline \multicolumn{2}{|c|}{ 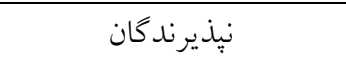 } & \multicolumn{2}{|c|}{ 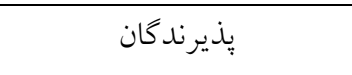 } & \multicolumn{2}{|c|}{ معادله انتخاب } & \multirow[b]{2}{*}{ 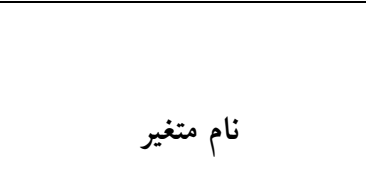 } \\
\hline خطاى معيار & ضريب & خطاى معيار & ضريب & خطاى معيار & ضريب & \\
\hline $0 / 9 \wedge r$ & $4 / 991$ \%****\% & r/TYq & 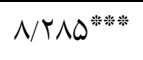 & $1 / \mu V_{0}$ & 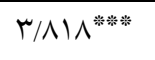 & آكُاهى از كيفيت خاك \\
\hline $0 / 199$ & $-0 / 09 r$ & OMYK & 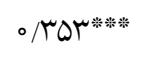 & $\circ / I V r$ & 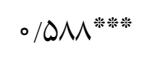 & دسترسى به اطلاعات \\
\hline o/NIT & $1 /\left.\Delta 0\right|^{*}$ & $\circ / V \circ \varphi^{t}$ & 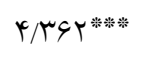 & $0 / 4 \& V$ & 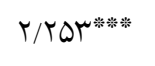 & دسترسى به اعتبارات \\
\hline $1 / 910$ & I/OTV & $\circ N G V$ & 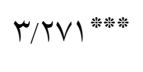 & $\circ / V Y V$ & 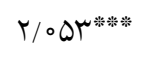 & شركت در كاسهاى ترويجى \\
\hline$\circ / 11 \mathrm{~V}$ & $0 / 094$ & $\circ /|V|$ & 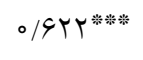 & $\circ / 140$ & $\circ / Y 9 V^{* * *}$ & تحصيلات \\
\hline $0 / 099$ & $-0 / Y Y V^{\text {**** }}$ & $\circ / \circ \wedge \uparrow$ & 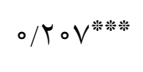 & o/VAT & $\circ / I V Y^{4 * * *}$ & 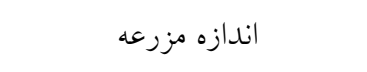 \\
\hline$\circ / 1$ TQ & $\circ / V Y Q$ & $\circ / 1$ TQ & ०/OTG & 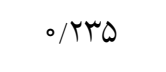 & $-\circ / \wedge 9 V^{* * * *}$ & تعداد قطعات زمين \\
\hline $0 / 0 \mathrm{kV}$ & $\circ / 001$ & $\circ / \circ \vee \circ$ & $-\circ / \circ \wedge \vee$ & $0 / 09 \mu$ & $-\circ / / Q r^{* * * *}$ & فاصله تا مركز خريد \\
\hline / & $\circ / \circ \circ \Delta$ & \%०० & $-0 / 001$ & \%०० & -०/००ケ" & هزينه آمادهسازى زمين \\
\hline$\circ / \circ \circ \psi^{r}$ & 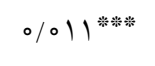 & ०/०० & O/O Y Y & ०००ץ & $-\circ / \circ \circ 9^{*}$ & هزينه كود \\
\hline ONYT & $r / r \circ r$ & $1 / 419$ & M/GKY & $1 / 1 V_{0}$ & $\Gamma / N \Lambda^{* * * *}$ & مالكيت ماشين آلات \\
\hline $0 / 049$ & $-\circ / \circ \circ \mathrm{V}$ & $0 / 091$ & ०/०人 & $\circ / \circ \Delta \Delta$ & $-0 / 090$ & سن \\
\hline & 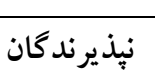 & & & & له انتخاب & \\
\hline
\end{tabular}

\begin{tabular}{|c|c|c|c|c|c|c|}
\hline خطاى معيار & ضريب & خطاى معيار & ضريب & خطاى معيار & ضريب & نام متغير \\
\hline & & & & $0 / 909$ & 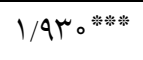 & درى كشاورز \\
\hline$\Delta / \Delta \Delta \wedge$ & $|\psi /| \wedge \circ$ & 9/00r & $-9 / v 11$ & $Y / \Lambda 1 Q$ & $-N / 9 r q$ & عرض از مبدأ \\
\hline$\circ / \Delta \mu_{0}$ & $-o / \Lambda V Y^{*}$ & $\circ / 4 \circ 0$ & $-0 / 01199$ & & & $\rho$ \\
\hline
\end{tabular}

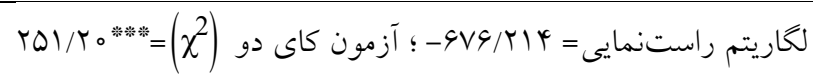

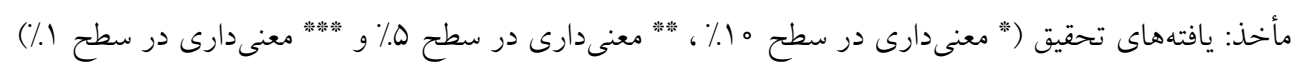


جدول r. نتايج حاصل از عوامل مؤثر بر پذيرش خاكورزى حفاظتى و اثر آن بر ميزان آب مصرفى بين دو گروه از يذيرند كان و نيذيرندكان

\begin{tabular}{|c|c|c|c|c|c|c|}
\hline \multicolumn{2}{|c|}{ 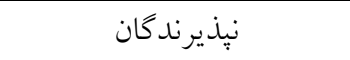 } & \multicolumn{2}{|c|}{ 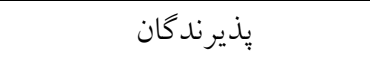 } & \multicolumn{2}{|c|}{ معادله انتخاب } & \multirow[b]{2}{*}{ نام متغير } \\
\hline خطاى معيار & ضريب & خطاى معيار & ضريب & خطاى معيار & ضريب & \\
\hline $0 / 99 \mathrm{~V}$ & $-0 / V 99$ & $0 / M G V$ & $-\circ / \Lambda \circ Y^{* * * *}$ &.$/ 09 \Lambda$ & $1 / \circ Q^{* * *}$ & آكاهى از كيفيت خاى \\
\hline 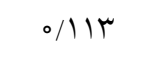 & $-0 / 010$ &.$/ 090$ & $-\circ / \sqrt[V]{9 Q^{* * *}}$ & $\circ / 091$ & 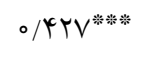 & دسترسى به اطلاعات \\
\hline$\circ / 4 V t$ & $-0 /$ rYq & $0 /$ M & 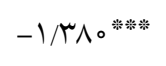 & $\circ / \wedge \Delta$ & $1 / \circ 0^{\text {क**** }}$ & دسترسى به اعتبارات \\
\hline $0 / 4$ ra & $1 / \Lambda V Y^{* * * * * *}$ & $\circ / \mathrm{VAl}$ & 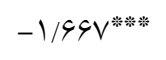 & $\circ / \Delta 0^{\circ}$ & 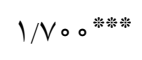 & شركت در كلاسهاى ترويجى \\
\hline$\circ / 0 V Y$ & $-0 / 109$ & $\circ / 090$ & $-0 / Y M Y \varphi^{* * * *}$ & $0 / 119$ & $\circ / \Gamma 9 Q^{* * * * * *}$ & تحصيلات \\
\hline ००० & $-0 / 0009$ & $\circ / \circ \circ Y$ & $\circ / \circ \circ \circ\rangle^{4}$ & $\circ / \Lambda Q Y$ & $0 / 19 r^{* * *}$ & اندازه مزرعه \\
\hline.$/ 90 \mathrm{~V}$ & $0 / Y \Delta \mid$ & O/YTD & -0/TYG & هr/I & -o/KY & تعداد قطعات زمين \\
\hline$\circ / \circ \Delta r$ & ०/०० & $\circ / \circ V^{f}$ & $-0 / 094$ & $\circ / \circ \Delta \wedge$ & $-0 / 1 Y Q^{* * *}$ & فاصله تا مركز خريد \\
\hline$\circ / \circ \circ \Delta$ & $\circ / \circ \circ V$ & $\circ / \circ \circ \psi^{f}$ & -०/०० & ०/०० & $-\circ / \circ \circ Q^{*}$ & هزينه آمادهسازى زمين \\
\hline$\circ / 0 \circ Y$ & $-\circ / \circ \circ 9^{* * * *}$ & $\circ / 0 \circ Y$ & 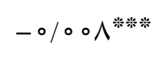 & $\circ / 0 \circ Y$ & $-\circ / \circ \circ Q^{* * * *}$ & هزينه كود \\
\hline.$/ 090$ & 1/0r & $|/| Y \mid$ & 1/OrT & $1 / 1 \wedge t$ & 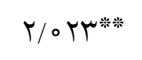 & مالكيت ماشين آلات \\
\hline$\circ / \uparrow \circ \circ$ & $\circ / \mathrm{N} \wedge$ & o/MYt & $-\circ / \mathcal{K} Y V^{* * * *}$ & $\circ / 409$ & 1/Nor絭 & حفظ بقاياى كياهى \\
\hline 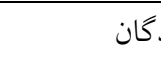 & & & يذير & تخخاب & معادل & \\
\hline خظاى معيار & ضريب & خطاى معيار & ضريب & خطاى معيار & ضريب & \\
\hline ०० Yq & \%००Y & \%० & $-0 / 0$ H $^{-1}$ & $0 \%$ 4 & $-0 / 019$ & سن \\
\hline \multirow[t]{2}{*}{$0 / 011$} & 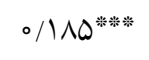 & .1004 & $-0 / 1 Y q^{* * * * * * * * 6}$ & $\circ / \circ \circ \wedge$ & $0 / 0001$ & توليد كل \\
\hline & & & & $\circ / 499$ & $1 / V \circ V^{\text {****** }}$ & درى كشاورز \\
\hline$r / \backslash Q Y$ & $-r / 900 \%$ & $r / N / 9$ & 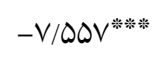 & T/VAN & $-9 / O Y I^{* * * *}$ & عرض از مبدأ \\
\hline o/4OR & $-\circ / \mathrm{V} 10^{*}$ & $0 / \mu 4 q$ & -o/VAY"*** & & & $\rho$ \\
\hline
\end{tabular}

STY/M

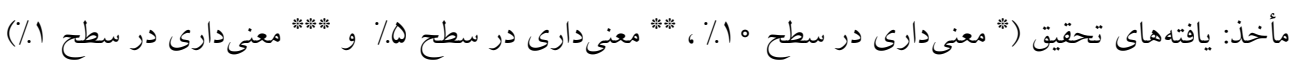


جدول ثا. نتايج حاصل از عوامل مؤثر بر بذيرش خاكورزى حفاظتى و اثر آن بر شكاف فقر بين دو گروه از بذيرندكان و نبذيرندكان

\begin{tabular}{|c|c|c|c|c|c|c|}
\hline \multicolumn{2}{|c|}{ 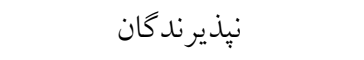 } & \multicolumn{2}{|c|}{ ي بذيرندكان } & \multicolumn{2}{|c|}{ معادله انتخاب } & \multirow{2}{*}{ 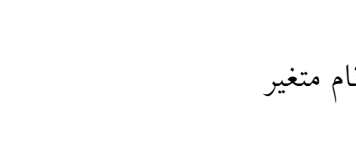 } \\
\hline خطاى معيار & ضريب & خطاى معيار & ضريب & خطاى معيار & ضريب & \\
\hline$\circ / 040$ & $-0 / 014$ & ०/OQVY & 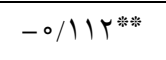 & $1 / 409$ & T/949* & آكاهى از كيفيت خاك \\
\hline .011 & $-0 / 0001$ & $\circ / \circ \circ \Delta$ & \%००YG & $\circ / \mathrm{Vr}$ & 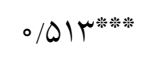 & دسترسى به اطلاعات \\
\hline$\circ / 04 V$ & 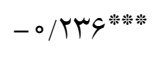 & $\circ / 0 Y q$ & $-109 r^{* * * * * *}$ & $\circ / \mathbb{F}$ G & O/YGY & دسترسى به اعتبارات \\
\hline $0 / 049$ & $\circ / \circ \Delta V \wedge$ & .090 & $-\circ / \Upsilon \wedge Q^{* * * * * *}$ & $\circ / M^{\mu}$ & $1 / T V_{0}^{* *}$ & شركت در كاس هاى ترويجى \\
\hline$\circ / \circ \circ \mathrm{V}$ & $-0 / 011$ & $\circ / \circ \circ V$ & $-0 / 01 Y 4^{*}$ & $0 / 149$ & $\circ / \mu 1 I^{\text {**** }}$ & تحصيلات \\
\hline$\circ \circ \circ \Delta$ & $-\circ / \circ \circ V$ & $\circ / \circ \mu^{2}$ & $0 / 0009$ & $\circ / \circ V$ & $\circ / \wedge Q^{* * *}$ & 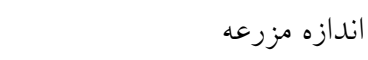 \\
\hline$\circ / 9 \circ 0$ & $\circ / \mu 1$ & $\circ / Y \circ \Delta$ & $-0 / 9 Y 4$ & o/ra & $-0 / 901^{* * *}$ & تعداد قطعات زمين \\
\hline$\circ \% \circ Y$ & ०/०००ץ &.$/ 0049$ & $\circ / \circ \circ Y$ & $\circ / 009$ & $-0 / 1 Y q^{* * * \%}$ & فاصله تا مركز خريد \\
\hline 1000Y & $\circ / 0 \circ \circ 9 * * *$ & $0 / 00009$ & $-0 / 001$ & ०००Y & $-0 / 0 \circ \varphi^{*}$ & هزينه آمادهسازى زمين \\
\hline ०००० & $-0 / 0 \circ 0 \psi^{*}$ & $\circ / 0001$ & $-0 / 0 \circ \circ Y^{*}$ & $\circ / 0 \circ Y$ & $-\circ / \circ \circ \Delta^{* * *}$ & هزينه كود \\
\hline o/०kt & $0 / 091$ & $\circ / \circ \Delta \wedge$ & 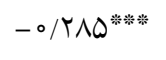 & $1 / \circ V Q$ & $1 / 99 V^{*}$ & مالكيت ماشين آلات \\
\hline$\circ / 040$ & $\circ \% \circ Y$ & $\circ \% \circ Y$ & $0 / 0009$ & $\circ / \circ 09$ & $-0 / 0 \mathrm{kr}$ & سن \\
\hline \multicolumn{2}{|c|}{ نيذيرند } & \multicolumn{2}{|c|}{ يذّيرند } & \multicolumn{2}{|c|}{ معادله انتخاب } & \\
\hline \multirow[t]{2}{*}{ خطاى معيار } & ضريب & خطاى معيار & ضريب & خطاى معيار & ضريب & \\
\hline & & & & $\circ / Q V Q$ & 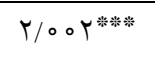 & درى كشاورز \\
\hline ( & $-0 / 191$ & O/YYA & $-0 / / \mu x$ & $Y / 1 / 0$ & $-V / \circ V Q$ & عرض از مبدأ \\
\hline ONKV & O/QAY* & $\circ / Y M$ & $0 / 091$ & & & $\rho$ \\
\hline
\end{tabular}

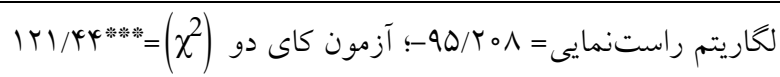

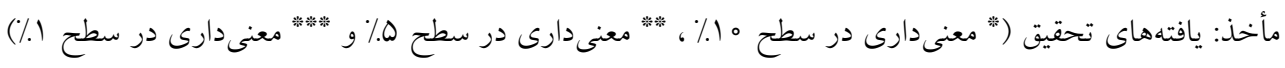

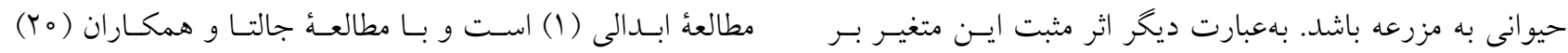

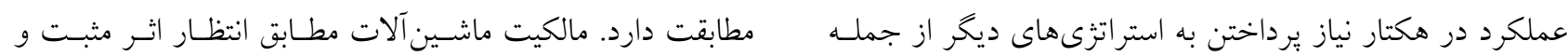

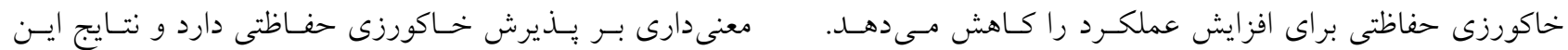

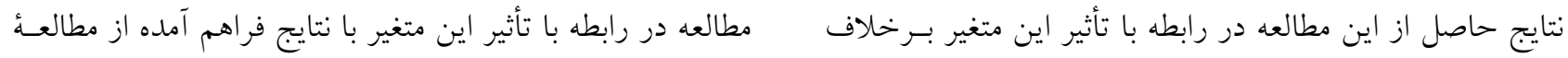


(9) استدلال مى كنند كه سن، شاخصى از تجربه است و ارتبـاط

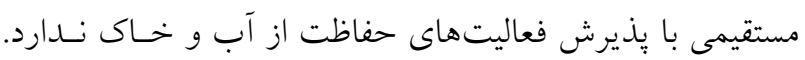

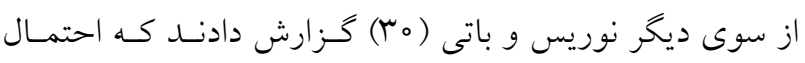

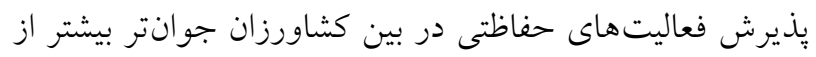

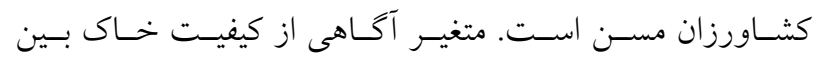

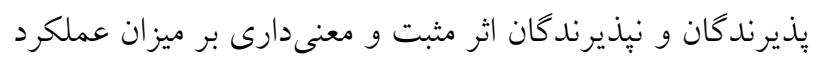

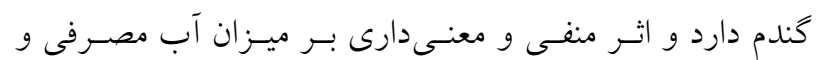

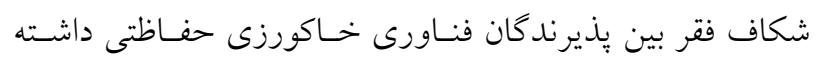

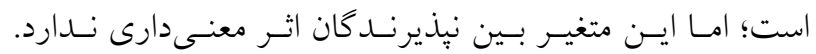

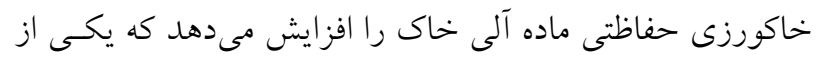
بهترين شاخصهاى سنجش كيفيت خاك است. اين افـزايش در

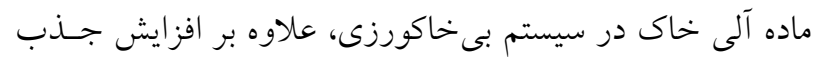

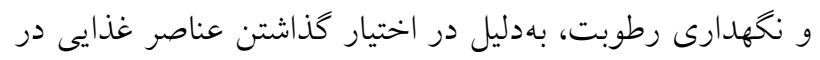

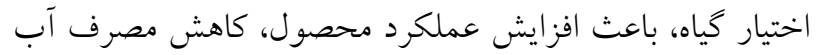

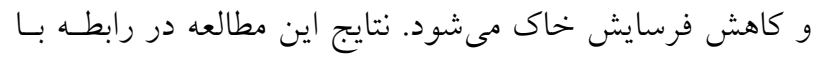

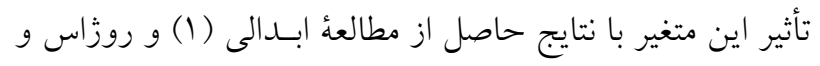

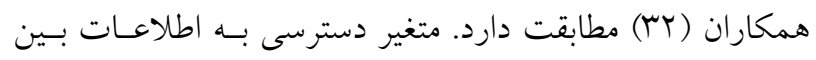

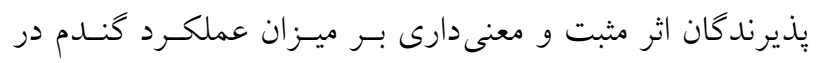

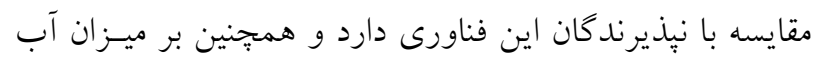

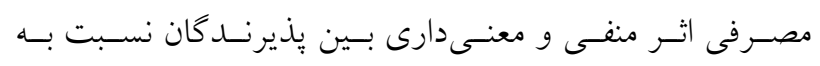

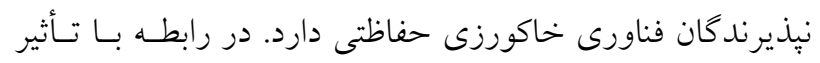

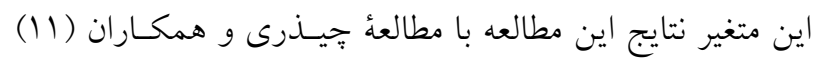

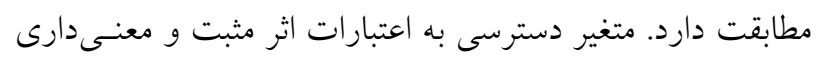

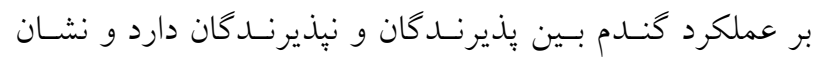

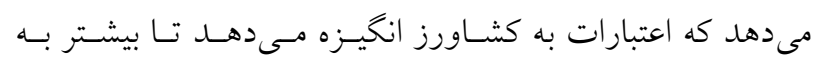

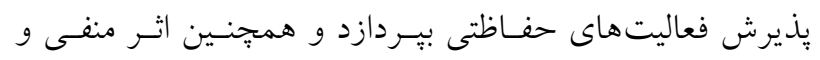

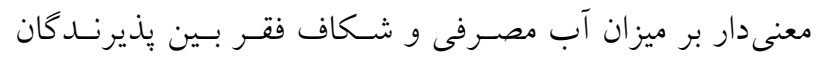

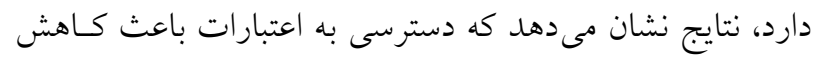

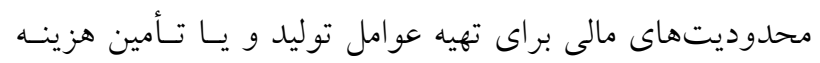

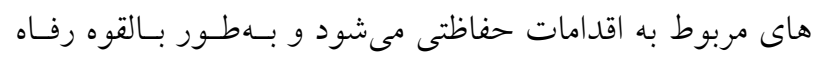

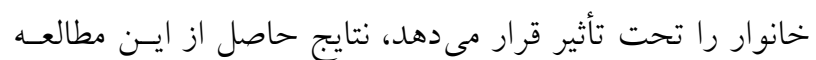

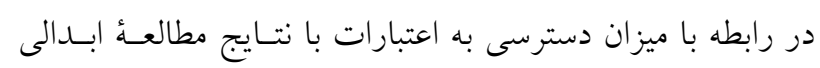

ابدالى (1) - مطابقت دارد.

بنابراين متغيرهـاى آخـاهى از كيفيـت خــاك، دسترسى بـهـ اعتبارات، دسترسى به اطلاعات، تحصـيلات، سـطح زيركشـت، مالكيت ماشين آلات، شـركت در كـلاس هـاى ترويجسى و درى كشاورز اثرات مثبت و معنى دارى بر احتمال بـــيرش دارنــــــر در مقابل، متغيرهاى فاصله تا مركز خريد و تعــاد قطعـات زمسين، اثرات منفى و معنى دارى بر يذيرش دارند.

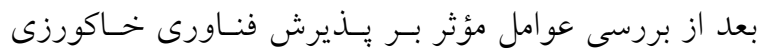

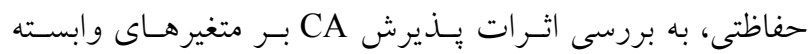
(عملكرد گندم، مصـرف آب و شـكاف فقـر) بـين دو گـروه از يذيرند گان و نيذيرند گان فناورى خـاكورزى حفـاظتى برداختـه شده است. جــدولهـاى (Y) تـا (Y)، بــهـترتيـب اتــر متغيرهـاى توضيحى را بر ميزان عملكرد گندم، حجم آب مصرفى و شكاف فقر در دو گروه از بذيرندكان و نيذيرندكان خاكورزى حفـاظتى نشان مىدهند. ضريب م مراى عملكرد در هكتار و حجـم آب مصرفى منفى و معنى دار و براى شكاف فقـر مثبـت و معنسىدار است كه نشاندهنده جهت گيرى (bias) انتخـاب بـهدليـل تـأثير عوامـل غيرقابـل مشــاهده در بكــار گيرى فنــاورى خــاكورزى حفاظتى است. بنابر اين اسـتفاده از روش رگرسـيون سـؤيجينگ درونزا كه هر دو عوامل قابـل مشـاهده و غيرقابـل مشـاهده را منظور مسى كنــ در مطالعـه حاضـر كـاملاً مناسـب بـوده اســت.

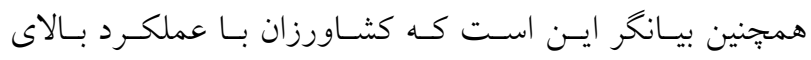
ميانگين، مصرف آب و شكاف فقر كمتر، احتمال بالاترى بـراى استفاده از فناورى CA دارند (كه با آنجه بهصـورت شهودى در منطقه مشاهده شد، مطابقت دارد). آماره حداكثر راستنمايى در بـر

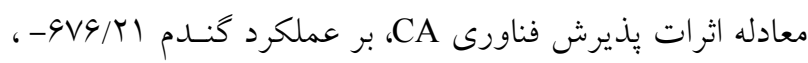

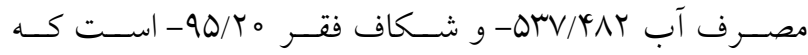
معنى

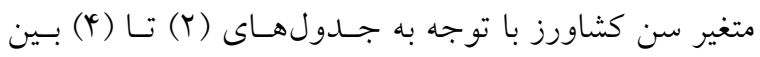
يذيرند گان و نيذيرند گان فناورى CA بر عملكرد گندم، مصسرف آب و شكاف فقر تأثيرى نداشـته اسـت. در مـورد ايسن بــارامتر مطالعات بيشين تفسيرهاى مختلفى ارائه دادهاند؛ امسالو و كرف 
همجنين بر ميزان آب مصرفى و شكاف فقر بـين دو كـروه از

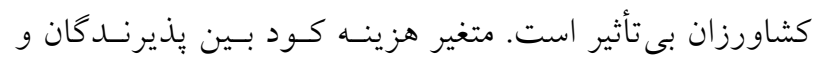

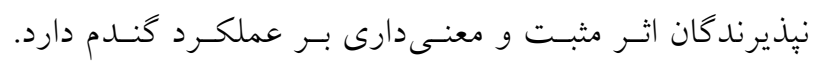

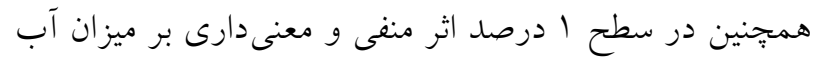

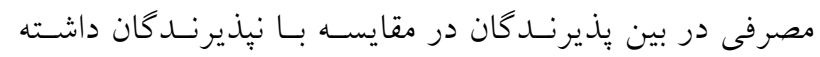

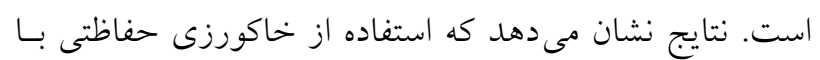

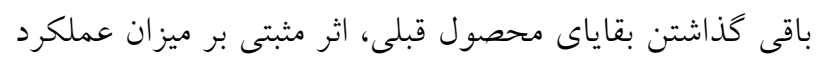

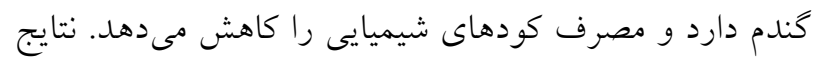

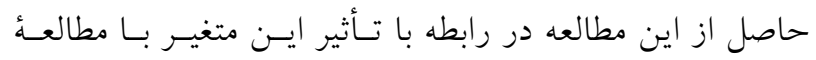

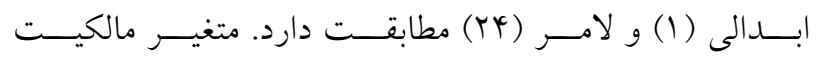
ماشين آلات اثر مثبت و معنسى دارى در سـطح له د درصــ بــين

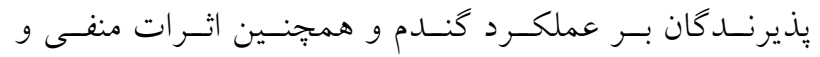

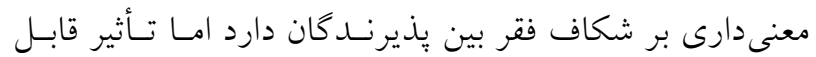

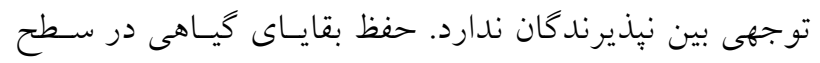

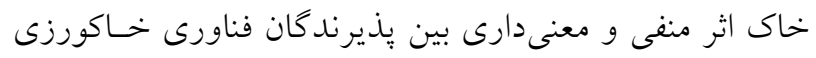

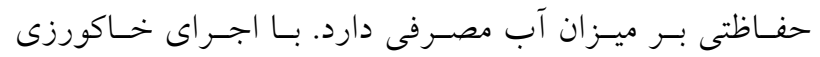

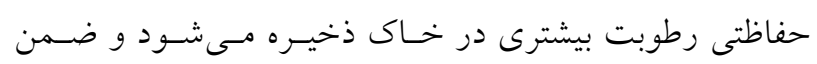
كاهش تبخير موجب افزايش نفوذيذيرى آب مسى شـود. نتسايج

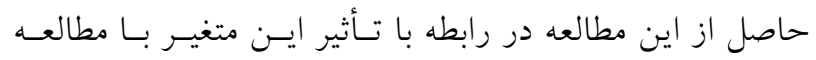
مزويمو و توملو (Y) مطابقت دارد.

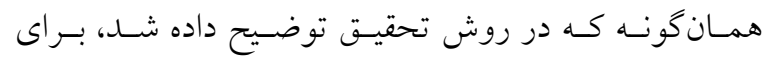

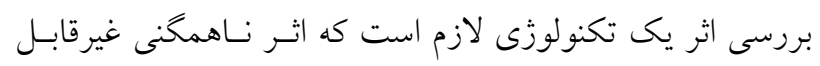

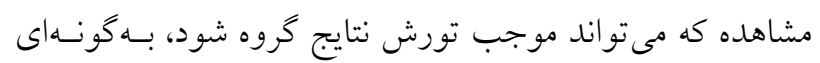

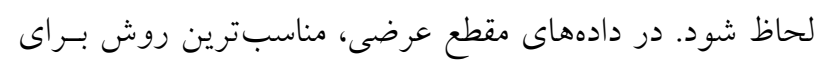

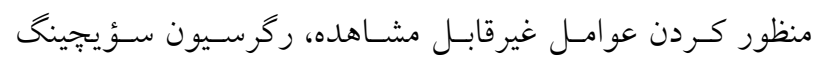

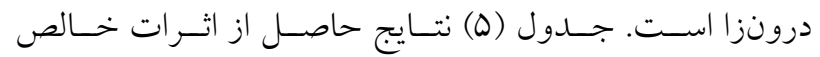

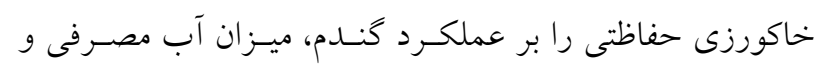

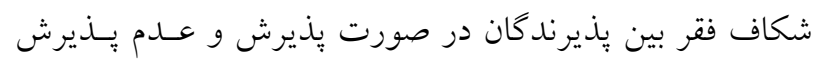

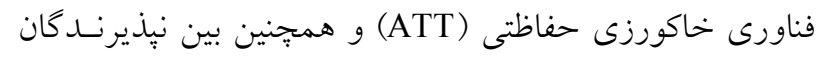

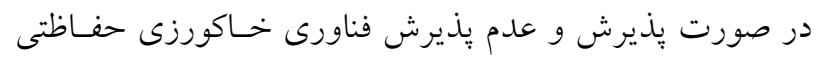

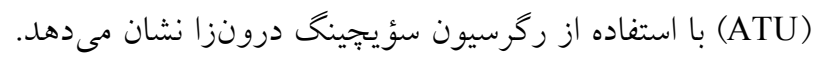

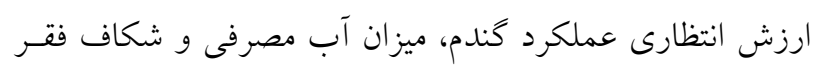

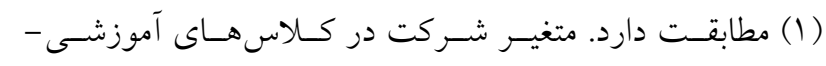

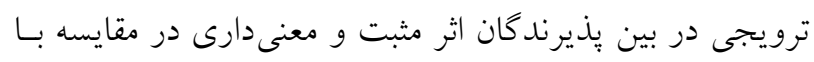

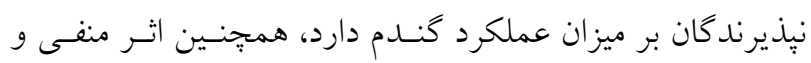

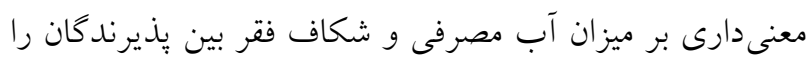

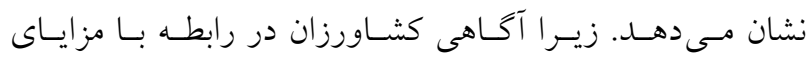

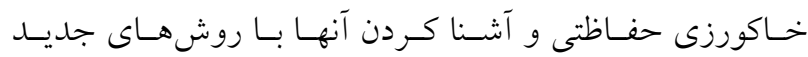
مى تواند باعث كاهش متوسط آب مصرفى در هـر هكتـار گَّـدم

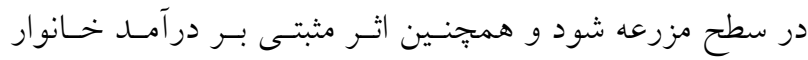

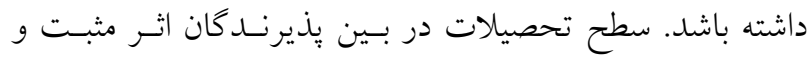

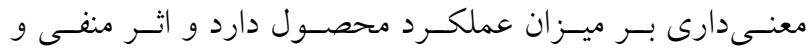

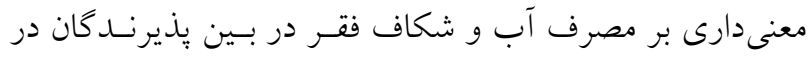

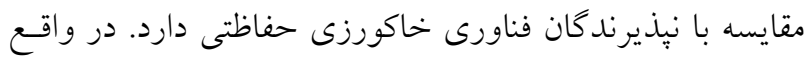

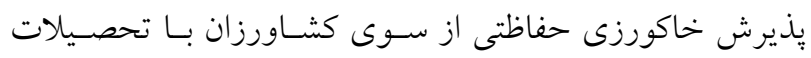
بالا، بر عملكرد در هكتار آنها اثر مثبـت و معنسى دارى بـهدنبـال

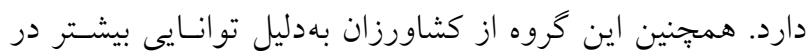

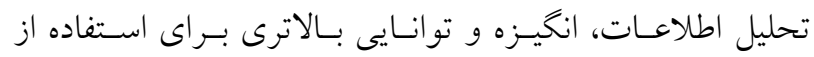

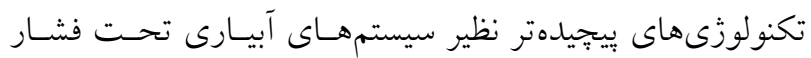

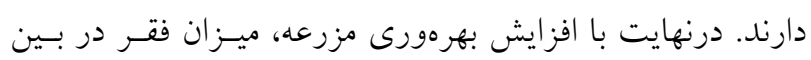

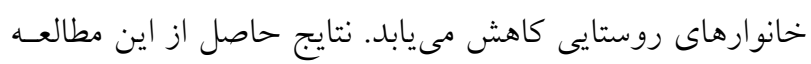

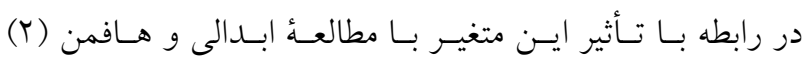

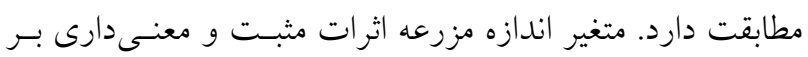

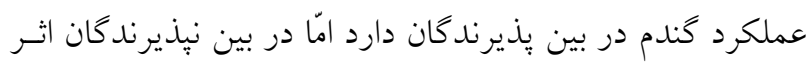

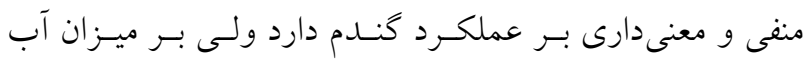

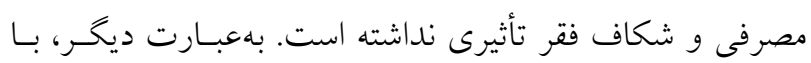

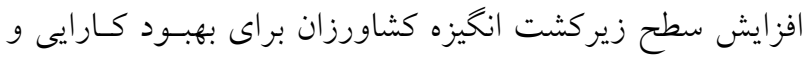
بهرهورى توليد افزايش مىيابد و بنابراين تمايل بيشترى نسبت

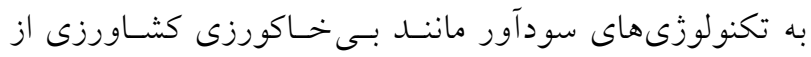

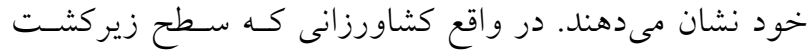
بيشترى دارند نسبت به كشـاورزان كوجـك مقيـاس ريسكـيذّيرتر و انخيزه بيشترى براى بكارگيرى فعاليتهاى خاكورزى

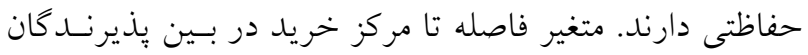

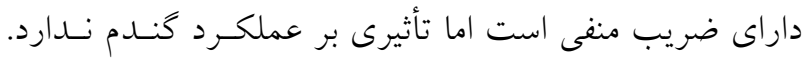


جدول ه. اثرات خالص خاكورزى حفاظتى بر عملكرد گندم، حجم آب مصرفى و شكاف فقر بين بذيرندگان و نيذيرندكان

\begin{tabular}{|c|c|c|c|}
\hline اثرات خالص CA & عدم يذيرش & 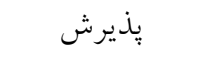 & متغيرها \\
\hline & & & عملكرد (هكتار) \\
\hline 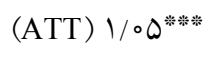 & $\varphi / \mu_{0}$ & $\Delta / 4 \Delta$ & 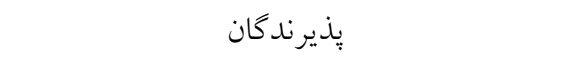 \\
\hline 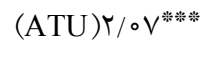 & $r / 4 \Lambda$ & $\Delta / \Delta \Delta$ & ن يذيرندكان \\
\hline \multirow[t]{2}{*}{$\mathrm{TH}=-1 / \circ \mathrm{r}$} & $\mathrm{BH}_{2}=\circ / 9 \mathrm{r}$ & $\mathrm{BH}_{1}=-\circ / 1$ & اثرات ناهمخنى \\
\hline & & & حجم آب مصرفى (مترمكعب به ازاى هرهكتار) \\
\hline 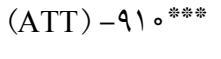 & $\wedge \vee \wedge 。$ & $\vee \wedge \vee 。$ & يذيرندكان \\
\hline$(A T U)-Y \Delta Y_{0}$ **** & $\wedge \vee \wedge 。$ & 9490 & 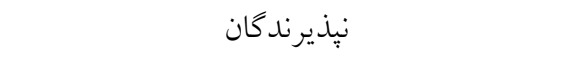 \\
\hline \multirow[t]{2}{*}{$\mathrm{TH}=191}$. & $\mathrm{BH}_{2}=。$ & $\mathrm{BH}_{1}=191 。$ & اثرات ناهمخنى \\
\hline & & & شكاف فقر (درصد) \\
\hline (ATT) $-\% \Upsilon_{0} 0^{* * * * * *}$ & $\%$ V^ & $\%$ \% & يذيرندكان \\
\hline$(\mathrm{ATU})-\% q^{* * *}$ & $\%$ & $\%$ & 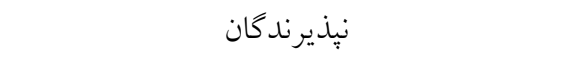 \\
\hline $\mathrm{TH}=-\% .9$ & $\mathrm{BH}_{2}=-\%$ & $\mathrm{~B} \mathrm{H}_{1}=\%$ & اثرات ناهمخنى \\
\hline
\end{tabular}

حفاظتى بر عملكرد گُندم بهطسور ميـانخين هـ/1/ تـن در هكتـار

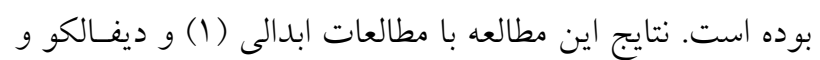

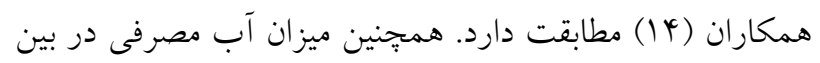

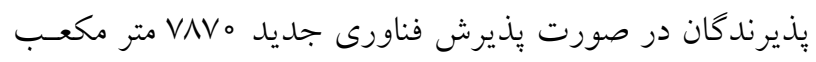

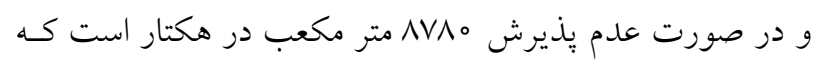

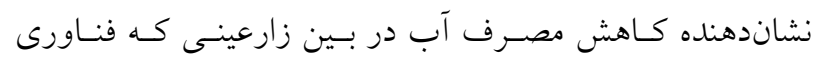

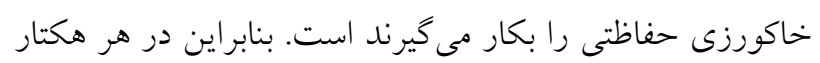

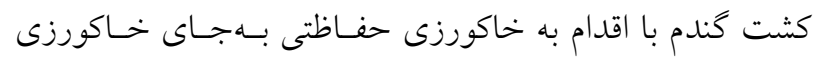

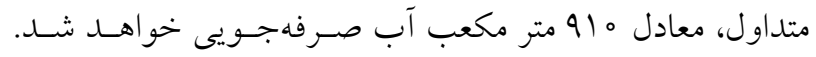

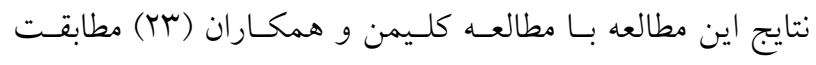

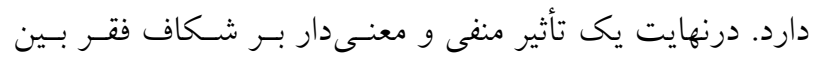

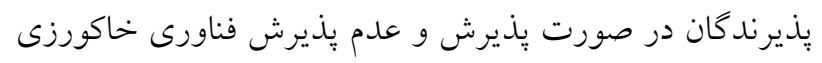

بين بذيرندكان در صورت بذ يذيرش فناورى (مشاهده شـده) و در

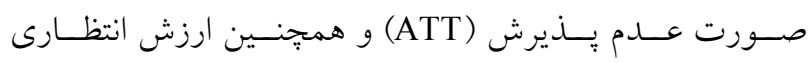

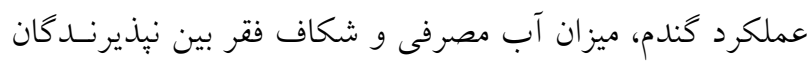

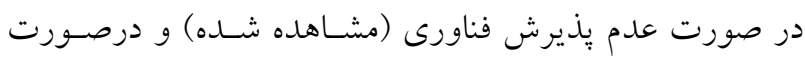

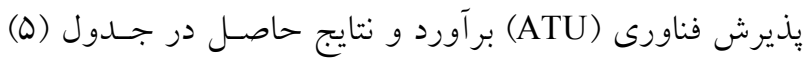

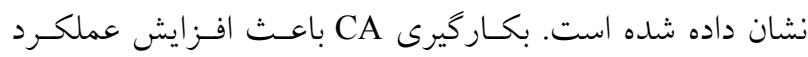

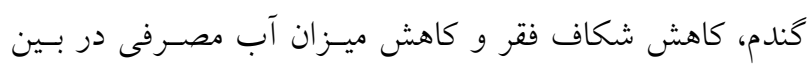

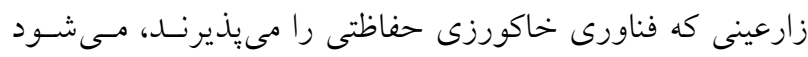

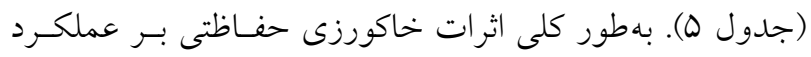

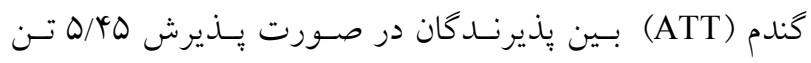

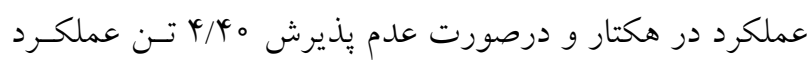

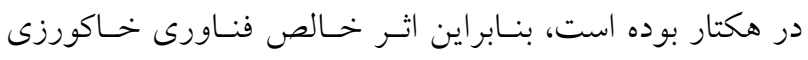


فناورىهاى خاكورزى حفاظتى و تأثير اين فنـاورىهـا بــر رفـاه

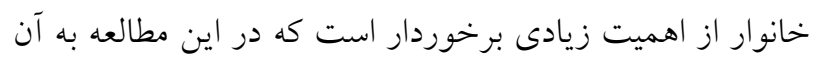

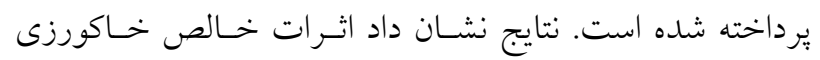

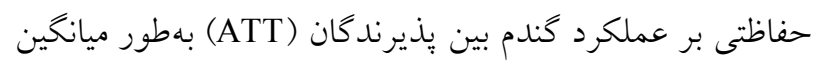

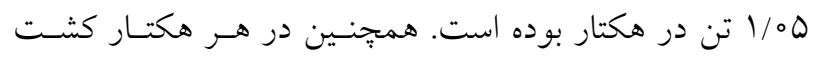

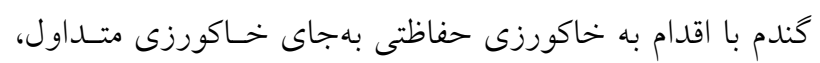

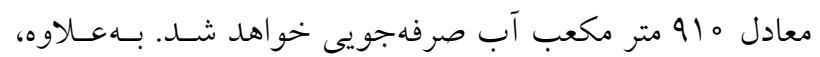

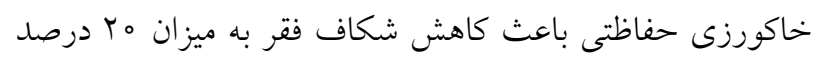

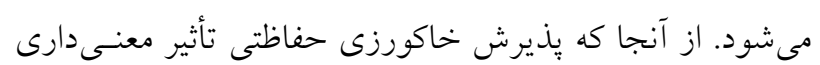

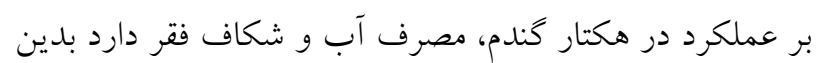

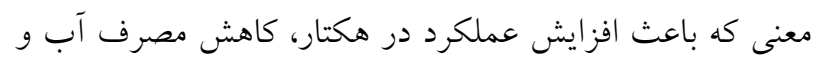

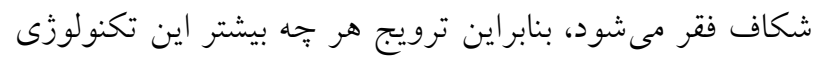

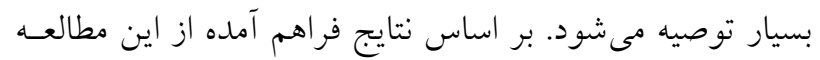

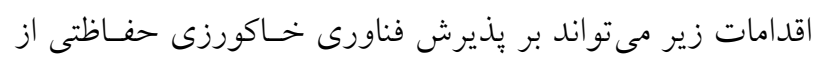

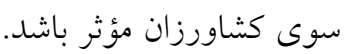

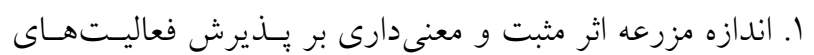

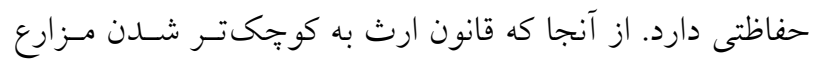

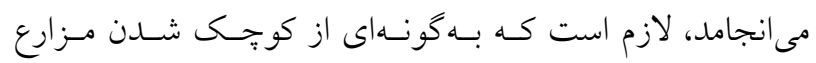

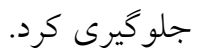
ז. ميزان دسترسى به اعتبارت و تسهيلات بـانكى اثـر مثبـت و و

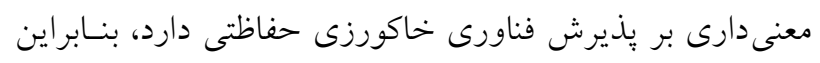

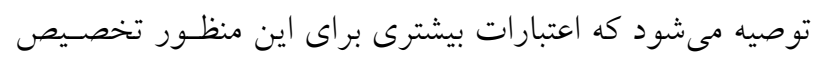

r. از آنجا كه بِراكندگى مزارع در بِذيرش فعاليتهـاى حفـاظتى

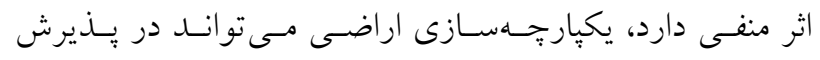

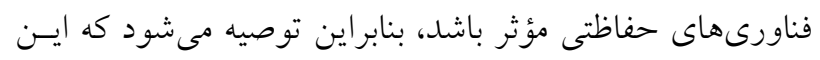
طرح با دقت بيشترى انجام شود.
حفاظتى را نشان مى دهد كه ميانخين شكاف فقر بين بذيرنسـدان

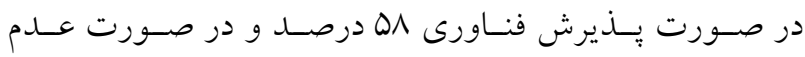

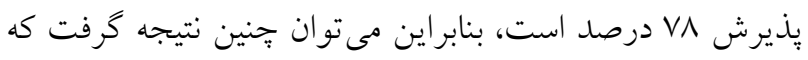

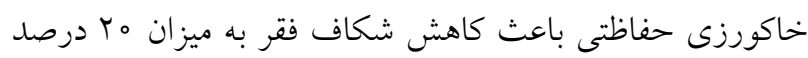

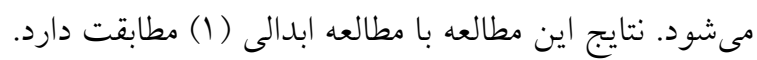

\section{نتيجه گيرى و بيشنهادات}

كشاورزى مدرن دسـتاوردهاى بزرخى در زمينـه افز ايش مـواد

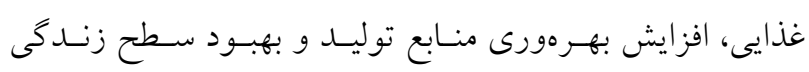

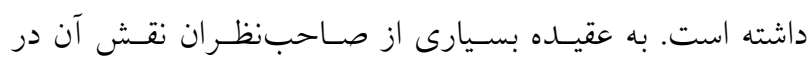
تأمين رفاه و امنيت غذايى جوامع قابل انكار نيست امـا بـهدليـل

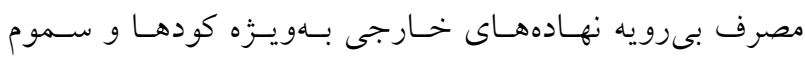

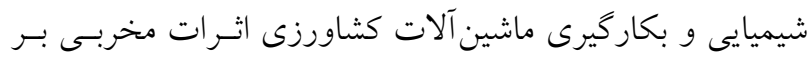
محيط زيست وارد ساخته است. بهطورى كه در دهلهـاى اخيـر بهدليل نكر انى از مشكلات زيستمحيطى، نظامهـاى كشـاورزى مدرن بهشدت مورد انتقاد قرار گرفته است. بهطور كلى اين باور

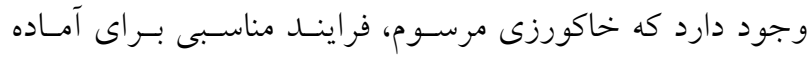

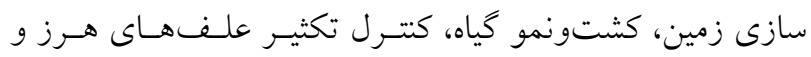

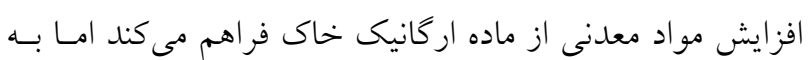

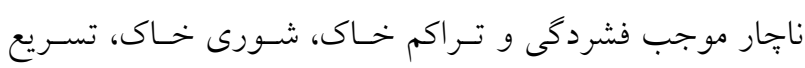

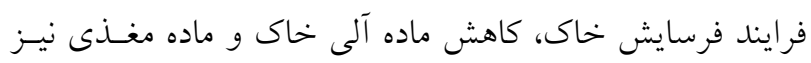

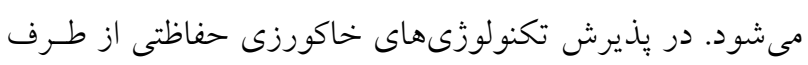

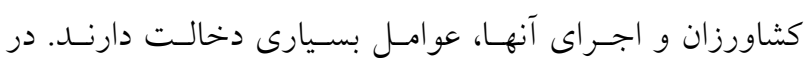
بسيارى از مو ارد تكنولوزى طراحى و معرفى مسى شـودة، امـا از

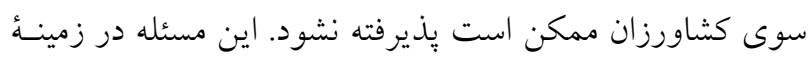

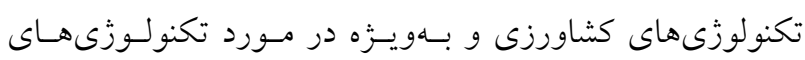

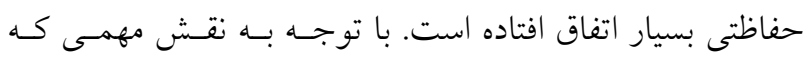

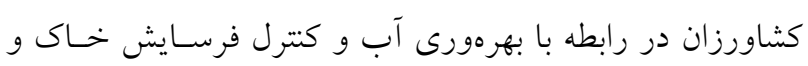

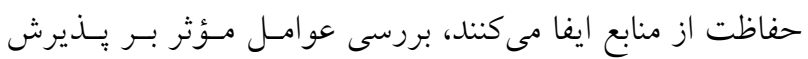


1. Abdulai, A. N. 2016. Impact of conservation agriculture technology on household welfare in Zambia. Agricultural Economics 47(6): 729-741.

2. Abdulai, A. and W. Huffman. 2014. The adoption and impact of soil and water conservation technology: An endogenous switching regression application. Land Economics 90(1): 26-43.

3. Abedi, S, S. Yazdani, A. Salehi, H. Salami and M. Jahansoz. 2014. Analysis of effective factors on the adoption of protective soil tillage in Fars province. Iranian Journal of Agricultural Economics and Research 45(2): 255-247. (In Farsi).

4. ACT, A. C. T. N. 2008. Linking production, livelihoods and conservation: Proceedings of the Third World Congress on Conservation Agriculture, 3-7 October.

5. Agricultural Jihad Organization of Zarghan Province. 2016. Agricultural Statistics Volume I, crops.

6. Amsalu, A. and J. De Graaff. 2007. Determinants of adoption and continued use of stone terraces for soil and water conservation in an Ethiopian highland watershed. Ecological Economics 61(2-3): 294-302.

7. Asfaw, S., B. Shiferaw, F. Simtowe and L. Lipper. 2012. Impact of modern agricultural technologies on smallholder welfare: Evidence from Tanzania and Ethiopia. Food Policy 37(3): 283-295.

8. Baradi, N. K. 2009. Factors affecting the adoption of tillage systems in Kansas, Doctoral dissertation, Kansas State University.

9. Becerril, J. and A. Abdulai. 2010. The impact of improved maize varieties on poverty in Mexico: a propensity scorematching approach. World Development 38(7): 1024-1035.

10. Carter, D. W. and J. W. Milon. 2005. Price knowledge in household demand for utility services. Land Economics 81(2): 265-283.

11. Chizari, M., S. Karimi, R. J. Lindner and G. Pezeshki-Rad. 2003. Perception of soil conservation competencies among farmers in Markazi Province, Iran. Journal of International Agricultural and Extension Education 10(3): 1319.

12. Cramb, R. A. 2007. Land and Longhouse: Agrarian Transformation in the Uplands of Sarawak (Vol. 110). NIAS Press.

13. Dehghanian, E. and S. Afzalinia. 2014. Effect of conservation tillage and irrigation regimes on winter wheat yield and water productivity. Tarım Makinalart Bilimi Dergisi 10(2): 144-155.

14. Di Falco, S., M. Veronesi and M. Yesuf. 2011. Does adaptation to climate change provide food security? A microperspective from Ethiopia. American Journal of Agricultural Economics 93(3): 829-846.

15. Di Falco, S. and M. Veronesi. 2013. How can African agriculture adapt to climate change? A counterfactual analysis from Ethiopia. Land Economics 89(4): 743-766.

16. Foster, J. E., J. Greera and E. Thorbecke. 1984. A class of decomposable poverty measures. Econometrica 52: 761776.

17. Grant, C. A. and G. P. Lafond. 1993. The effects of tillage systems and crop sequences on soil bulk density and penetration resistance on a clay soil in southern Saskatchewan. Canadian Journal of Soil Science 73(2): 223-232.

18. Griffith, D. R., J. V. Mannering and W. C. Moldenhauer. 1977. Conservation tillage in eastern corn belt. Journal of Soil and Water Conservation 32(1): 20-28.

19. Gürsoy, S. 2012. Evaluation of the no-till demonstration studies in south east Anatolia region of Turkey. AGRIS Online Papers in Economics and Informatics 4(3): 21-38.

20. Jaleta, M., M. Kassie, K. Tesfaye, T. Teklewold, P. R. Jena, P. Marenya and O. Erenstein. 2016. Resource saving and productivity enhancing impacts of crop management innovation packages in Ethiopia. Agricultural Economics 47(5): 513-522.

21. Kassam, A., T. Friedrich, F. Shaxson and J. Pretty. 2009. The spread of conservation agriculture: justification, sustainability and uptake. International Journal of Agricultural Sustainability 7(4): 292-320.

22. Khonje, M., J. Manda, A. D. Alene and M. Kassie. 2015. Analysis of adoption and impacts of improved maize varieties in eastern Zambia. World Development 66(6): 695-706.

23. Kleemann, L., A. Abdulai and M. Buss. 2014. Certification and access to export markets: Adoption and return on investment of organic-certified pineapple farming in Ghana. World Development 64(10): 79-92.

24. Lahmar, R. 2010. Adoption of conservation agriculture in Europe: lessons of the KASSA project. Land use policy 27(1): 4-10.

25. Marenya, P. P. and C. B. Barrett. 2007. Household-level determinants of adoption of improved natural resources management practices among smallholder farmers in western Kenya. Food Policy 32(4): 515-536.

26. Mazvimavi, K. and S. Twomlow. 2009. Socioeconomic and institutional factors influencing adoption of conservation farming by vulnerable households in Zimbabwe. Agricultural Systems 101(1): 20-29. 
27. Moghadam, R., G. Dinpanah and F. Zand. 2013. Factors influence on economic-social effectiveness of watershed and natural resources plans. European Journal of Experimental Biology 3(5): 400-406.

28. Mohammad, W., S. M. Shah, S. Shehzadi and S. A. Shah. 2012. Effect of tillage, rotation and crop residues on wheat crop productivity, fertilizer nitrogen and water use efficiency and soil organic carbon status in dry area (rainfed) of north-west Pakistan. Journal of Soil Science and Plant Nutrition 12(4): 715-727.

29. Mousavi, G., M. Asudar and B. Pour-Mohammadi. 2013. Effect of soil tillage methods, planting pattern and waste management on water use efficiency of canola. Eighth National Congress on Agricultural Machinery (BioSystem) and Mechanization of Iran. (In Farsi).

30. Norris, P. E. and S. S. Batie. 1987. Virginia farmers' soil conservation decisions: An application of Tobit analysis. Journal of Agricultural and Applied Economics 19(1): 79-90.

31. Rockström, J., C. Folke, L. Gordon, N. Hatibu, G. Jewitt, F. P. De Vries and R. Schulze. 2004. A watershed approach to upgrade rainfed agriculture in water scarce regions through Water System Innovations: an integrated research initiative on water for food and rural livelihoods in balance with ecosystem functions. Physics and Chemistry of the Earth, Parts A/B/C 29(15): 1109-1118.

32. Rojas, C., J. Pino, C. Basnou and M. Vivanco. 2013. Assessing land-use and-cover changes in relation to geographic factors and urban planning in the metropolitan area of Concepción (Chile). Implications for biodiversity conservation. Applied Geography 39: 93-103.

33. Thierfelder, C. and P. C. Wall. 2009. Effects of conservation agriculture techniques on infiltration and soil water content in Zambia and Zimbabwe. Soil and Tillage Research 105(2): 217-227.

34. Teklewold, H., M. Kassie, B. Shiferaw and G. Köhlin. 2013. Cropping system diversification, conservation tillage and modern seed adoption in Ethiopia: Impacts on household income, agrochemical use and demand for labor. Ecological Economics 93(6): 85-93.

35. Vignola, R., T. Koellner, R. W. Scholz and T. L. McDaniels. 2010. Decision-making by farmers regarding ecosystem services: factors affecting soil conservation efforts in Costa Rica. Land Use Policy 27(4): 1132-1142.

36.Zentner, R. P., D. D. Wall, C. N. Nagy, E. G. Smith, D. L. Young, P. R. Miller and A. M. Johnston. 2002. Economics of crop diversification and soil tillage opportunities in the Canadian prairies. Agronomy Journal 94(2): 216-230. 


\title{
Effects of Conservation Tillage Technology Adoption on Wheat Yield, Water Use and Household Poverty
}

\author{
S. Motalebani, M. Zibaie and A. Sheikhzeinoddin ${ }^{1^{*}}$
}

(Received: June 1-2019; Accepted: January 21-2020)

\begin{abstract}
The interaction of population growth, technological improvement and climate change have impacted severely on agricultural and environmental sustainability. In Iran, conventional tillage practice has resulted in soil erosion and loss of soil organic matter. In this regard, Conservation Agriculture (CA) forms part of this alternative paradigm to agricultural production systems approaches and can be regarded as a means to enhancing food productivity, reducing poverty, and mitigating the consequences of climate change in rural households. The objectives of this study were to examine the determinants and impacts of CA technology on wheat yield, poverty gap and water use. To this end, an endogenous switching regression (ESR) model was employed to estimate the impacts of CA technology on continuous variables such as wheat yield, poverty gap and water use. A sample of 260 farmers from Zarghan district was selected for interview collection of necessary farm level data. The results indicated that in the select equation of ESR model, ten coefficients (out of 12) are significant at the 5\% level or higher. Knowledge of soil quality, access to credit, access to information, education, farm size, ownership of machinery, participation in agricultural extension activities and farmer' perception have positive and significant effects on the probability of adopting CA. In contrast, variables such as the distance to shopping center and number of land parcels have negative and significant influence on adoption. Also, the results of ESR model and counterfactual analysis showed that wheat yield would increase by 1.05 tons and poverty gap and water use would decrease by $20 \%$ and 910 cubic meters per hectare respectively if farmers adopt CA technology.
\end{abstract}

Keywords: Endogenous switching regression model, Counterfactual analysis, Sustainable management, Zarghan.

1. Department of Agricultural Economics, Shiraz University, Shiraz, Iran.

*: Corresponding author, Email: azeinoddin@shirazu.ac.ir 